Graduate Institute of International and Development Studies

International Economics Department

Working Paper Series

Working Paper No. HEIDWP01-2017

\title{
The Consumption Response to Minimum Wages: Evidence from Chinese Households
}

\author{
Ernest Dautovic \\ University of Lausanne \\ Harald Hau \\ Yi Huang \\ Graduate Institute Geneva \\ Chemin Eugène-Rigot 2 \\ P.O. Box 136 \\ CH - 1211 Geneva 21 \\ Switzerland
}

University of Geneva and Swiss Finance Institute

(C) The Authors. All rights reserved. Working Papers describe research in progress by the author(s) and are published to elicit comments and to further debate. No part of this paper may be reproduced without the permission of the authors. 


\title{
The Consumption Response to Minimum Wages: Evidence from Chinese Households
}

\author{
Ernest Dautovic* \\ University of Lausanne \\ Harald $\mathrm{Hau}^{\dagger}$ \\ University of Geneva and Swiss Finance Institute \\ Yi Huang $\ddagger$ \\ Graduate Institute Geneva
}

\begin{abstract}
This paper evaluates the Chinese minimum wage policy for the period 2002-2009 in terms of its impact on low income household consumption. Using a representative household panel, we find support for the permanent income hypothesis, whereby unanticipated and persistent income increases due to minimum wage policy change are fully spent. The impact is driven by households with at least one child. We infer significant positive welfare effects for low income households based on expenditure increases concentrated in health care and education, whereas a negative employment effect of higher minimum wage cannot be confirmed.
\end{abstract}

JEL Classification: E24, J38, C26

Keywords: Minimum wages; Labor income; Household consumption; Permanent income hypothesis

\footnotetext{
*Faculty of Business and Economics, Internef, CH-1015 Lausanne, Switzerland. E-mail: ernest.dautovic@unil.ch

${ }^{\dagger}$ Geneva Finance Research Institute, 42 Boulevard du Pont d'Arve, CH-1211 Genève 4, Switzerland. E-mail: prof@haraldhau.com. Web page: http://www.haraldhau.com.

${ }^{\ddagger}$ Maison de la paix, Chemin Eugène-Rigot 2, CH-1202 Genève, Switzerland. E-mail:yi.huang@graduateinstitute.ch Acknowledgments: We thank Jean-Louis Arcand, Marius Brülhart, David Card, Eric French, Wei Huang, Gian-Paolo Klinke, Olivier Cadot, Rafael Lalive, Albert Park, Dominic Rohner, Li Shi, Stephanos Vlachos, Gewei Wang, Shangjin Wei for valuable comments on earlier drafts of the paper. We also thanks seminar participants at the research days of the Faculty of Business and Economics at the University of Lausanne. This research project benefited from a Sinergia Research Grant from the Swiss National Science Foundation (SNSF).
} 


\section{Introduction}

Minimum wage policies are among the most controversial public policies not only in developed countries, but also in emerging economies. In China, the minimum wage policy has been reformed after 2003 and enforced throughout a labor market with more than 800 million workers. But how effective were these minimum wage policies in improving income, consumption and welfare of low income households?

This paper analyzes the effect of the minimum wage level on consumption spending in a representative panel of Chinese households for the period 2002-2009. Household consumption provides a particularly relevant metric of welfare because it is often better measured and less volatile than income, Deaton (1997), Deaton and Grosh (2000). ${ }^{1}$ The effectiveness of minimum wage policies in developing countries has been questions for fears about unemployment risk, threats to an already precarious industrial competitiveness, and employment substitution into the informal labour market, Rama (2001), Fang and Lin (2015). And there are additional concerns why higher minimum wages may fail to translate into higher levels of consumption: first, higher minimum wages may simply substitute for other social transfers so that the effective income increase is considerably attenuated. Many social transfer programs are conditioned by income thresholds and cumulative effect of ineligibility is hard to evaluate in practice. Second, the disposable income effect of higher minimum wages may be perceived as transitory - particularly in emerging countries with higher price inflation. Consumption smoothing may then result only in modest consumption and welfare increase. Third, higher minimum wages may increase unemployment risk, raise precautionary saving and again attenuate the consumption effect. Fourth, the higher frequency of unemployment can make some households much worse off than in the previous policy regime. ${ }^{2}$

Against the background of these concerns, our study is the first to estimate the consumption and income response of Chinese households to the large cross-sectional and intertemporal variation of China's minimum wages. For the period 2000-2009, we identify more than 13,874 changes in the local minimum wage across China's 2,183 counties and 285 cities and match them to the urban household survey (UHS) which covers 73,164 urban household-year observations. The study finds that minimum wage increases in China functioned as a very effective tool for increasing the consumption level of low income households. Similarly to the evidence from the U.S., Neumark and Wascher (2011), local minimum wage hikes complement (rather than substitute) other social transfers so that labor income and transfer income often tend to increase simultaneously in minimum wage recipient households. The

\footnotetext{
${ }^{1}$ In the development economics literature consumption is the standard measures to assess the relative poverty of households. The World Bank relies on consumption measures to construct the international extreme poverty line, recent update brings it to $\$ 1.25$ per day at purchasing power parity (PPP) rates, Ravallion et al. (2009).

${ }^{2}$ For the effects of minimum wages on employment in the U.S. see for example the contributions of Krueger and Card (1995) and Card and Krueger (2000) juxtaposed to Neumark and Wascher (1992) and the recent evidence of Dube et al. (2010), Allegretto et al. (2011), Neumark et al. (2014a), Neumark et al. (2014b), Allegretto et al. (2016). The literature on the employment effect of minimum wages in developing countries is briefly surveyed in Section 6 .
} 
measured total income effect is thereby magnified: RMB 1,000 labor income increase due to a minimum wage hike implies RMB 1,500 labor income increase in poorest households due to multiple minimum wage earners within a family and comes with an additional average RMB 1,000 in transfer income. This suggests that local minimum wage increases in China are part of a more comprehensive social policy change toward low income households. It is consistent with local political leaders' promotions which hinge primarily on economic performance of their county. At the same time, high income households do not experience commensurate increases in their transfer income whenever minimum wages raise.

Second, we show that low income households spend the entire additional income coming from a higher minimum wage. As the minimum wage shock itself is difficult to predict and the associated income effect highly persistent, we can interpret this evidence as confirmation of the permanent income hypothesis. We perform both reduced form estimations, which relate consumption changes directly to the increase in the annual minimum wage, as well as two-stage least square estimations (2SLS), which use the minimum wage increase as an instrument for household income in the consumption function. Both methods provide consistent results and do not reject the permanent income hypothesis. The consumption elasticity to (permanent) income does not differ significantly when we consider liquidity constrained households. Only households without a child feature significantly lower consumption elasticity, which points to higher old-age savings.

The literature on the effects of minimum wages on consumption is scant, particularly for developing countries. A few studies have investigated the impact of minimum wages on durable and non-durable consumption for U.S. states. Aaronson et al. (2012) estimate a positive expenditure effect for minimum wage dependent U.S. households, and conclude that most of the consumption is due to vehicle purchases. Similarly, Alonso (2016) employs sales data to find that a 10\% increase in minimum wages increases non-durable consumption by $1 \%$ at an aggregate county level, and shows that the increase is greater in poorer counties. The effect of minimum wage changes on other wages and labor income in developing countries is better documented. Using labor survey data from Indonesia, Rama (2001) estimates the impact of doubling the minimum wage on the entire wage distribution, and finds that wages above the minimum wage also increased between 5-15\%. Bosch and Manacorda (2010) find that all growth inequality in income earnings in Mexico is due to the decline in the real value of the minimum wage. Engbom and Moser (2016) study the impact of the minimum wage change in Brazil on the reduction of earnings inequality and conclude that minimum wages help reduce earnings inequality in formal sectors of the economy and that the decline is more pronounced at the bottom of the wage distribution.

Research on developing countries has generally considered alternative income shocks to estimate consumption elasticities. Wolpin uses weather induced income shocks in India to estimate a consumption elasticity to income in the range 0.91-1.02 depending on the definition of consumption. 
Related work by Paxson studies weather shocks in Thailand to estimate the saving propensity to income shocks related to weather conditions; the estimated saving propensity to positive and persistent weather shocks is found to be greater than zero, but small. Nevertheless, while weather shocks or other disasters can have relatively persistent income effects, they may not always amount to permanent income changes.

Negative employment effects of minimum wage increases have always been a key policy concern. In the Chinese context, we do not find that higher minimum wages increase unemployment in urban low income households. While various point estimates for the employment elasticity of high minimum wages are negative, their economic and statistical significance remain low across various model specifications. This absence of negative employment effects could be explained by the extremely low minimum wage level in China, which is generally below $20 \%$ of the median wage compared to around $30 \%$ in the U.S. or up to $60 \%$ in France and Sweden, Dickens (2015). At such a low minimum wage level, even low productivity workers can typically find a new job after being fired. Evidence of a higher turnover rates in counties with an increase in minimum wages supports this interpretation. ${ }^{3}$

The effect of minimum wages on employment in China is disputed. Using firm-level data from border regions subject to different minimum wage changes, Huang et al. (2014) find a small and negative relation between Chinese minimum wages and firm employment. However, employment flows out a firm sample may not be synonymous with more unemployment. Unlike household survey data, firm-level data cannot not track the employment history of a worker. Fang and Lin (2015) find small negative employment effects of minimum wages using the Chinese urban household panel. Their estimated employment elasticity to minimum wage hikes is -0.05 in the full sample and -0.09 among young adults. However, these results appear fragile to the inclusion of county-level trends, which the authors do not account for.

Our paper is organized as follows. Section 2 explains China's minimum wage regulation, the persistence in the behavior of real minimum wages and the urban household survey. Section 3 discusses the research design. Section 4 presents the main results on the impact of minimum wage level on total household consumption. Here we also highlight the important role of minimum wages in determining a household's health and education expenditure. The role of household heterogeneity for consumption behavior is discussed in Section 5 with a focus on financial constrains and family structure. Section 6 explores the effect of minimum wages in explaining (un-)employment and job turnover for low wage workers. In Section 7, we run a placebo test and Section 8 concludes.

\footnotetext{
${ }^{3}$ Moreover, developing countries feature much larger informal labor markets, which can absorb workers who have lost their job in the formal sector, Comola and De Mello (2011). Meghir et al. (2012) elaborate on this mechanism in a labor market model with search frictions.
} 


\section{Data}

\subsection{Minimum Wage Regulation and Behavior}

Chinese minimum wage legislation was first enacted in 1994 following a wave of economic liberalization policies and the transition from predominantly state-owned production to a mixed economy with a growing private sector. Its implementation was poor and it lacked provisions and rules for the adjustment to price inflation and local economic conditions. It also suffered from lax enforcement and non-compliance. Rawski (2003), Du and Wang (2008), Zhongwei and Binbin (2011), Ye et al. (2015).

In December 2003, the central government opted for a reform of minimum wage regulation. Following China's access to the World Trade Organization in 2002, the ensuing increase in foreign direct investment and the related boom of the manufacturing sector added pressure for stricter minimum wage regulation. In March 2004, the Ministry of Labor and Social Security introduced the new Minimum Wage Regulations (MWR) into Chinese Labor Law. The most significant provisions required indexation of the minimum wage to the cost of living and a minimum wage level sufficient to support basic daily needs of employees. Local authorities were required to review the minimum wage at least every two year in light of local economic conditions and propose a revised minimum wage to the provincial authorities. ${ }^{4}$ Moreover, implementation of the new MWR was strengthened by increased control at the local administrative level and firm level in pursuit of better compliance. Penalties for non-compliance increased from $20-100 \%$ of the statutory minimum wage to $100-500 \%$.

The data used in this study were collected by Chinese Ministry of Human Resources and report the local minimum wage in 2,183 counties and 285 cities for the period 1994-2012. The main variable of interest is the hourly minimum wage imposed in a county or city. The hourly rate can be extrapolated to an effective monthly minimum wage adopting a standard 40 hours working week as stipulated in Article 33 of the Chinese Labor Law. ${ }^{5}$ To match the minimum wage data to the annual frequency of the household survey, we construct an annual real minimum wage by averaging effective monthly real minimum wages.

In line with the new MWR, large productivity growth and a booming manufacturing sector, real minimum wage growth in China was $8.7 \%$ in the period 1996-2003 and accelerated to $12.8 \%$ in the period 2004-2012. The average annual real minimum wage was only RMB 1,259 (\$441 under PPP) in 1996, but had increased to RMB 4,610 (\$1,309 under PPP) in $2012 .{ }^{6}$ In the same period, the annual real growth rate of Chinese labor productivity was $8.9 \%$, while real GDP oscillated around $9.7 \% .^{7}$ In

\footnotetext{
${ }^{4}$ The province is the highest administrative division in China, followed by cities and counties. There are 34 provinces in the Chinese administrative subdivision as of April 2015, 333 prefecture-level cities and a total of 2,862 county-level divisions in China.

${ }^{5}$ Details on Chinese Labor Law can be consulted at: http://www.china.org.cn/living_in_china/abc/2009-07/15/ content_18140508.htm

${ }^{6}$ Effective annual nominal minimum wage increased from RMB 2,628 (\$921 under PPP) in 1996 to RMB 13,224 $(\$ 3,756$ under PPP) in 2012.

${ }^{7}$ Purchasing power parity conversion factors are from the World Bank's International Comparison Program Database,
} 
other terms, China's average real minimum wage started slightly above the international poverty line set at $\$ 1$ per day in 1996 , and increased to a remarkable $\$ 3.55$ per day in two decades.

Table 1 illustrates that Chinese minimum wages are generally set at very low levels relative to the median wage. The average ratio of the minimum wage relative to the median wage (also referred to as the minimum wage "bite") fluctuates around $20 \%$ in the period 2002-2006 and then declines to $17.6 \%$ in 2009. Minimum wages never approached the much higher levels observed in some developed countries, where the minimum wage bite ranges from around $30 \%$ in the U.S. to $60 \%$ in France and Sweden, Dickens (2015). Therefore, the labor income and living conditions of minimum wage workers in China are much worse in relative terms compared to minimum wage workers in high income economies. In absolute terms, the Chinese minimum wage income of a single worker is close to the international poverty line: it follows that any policy measure that increases the consumption level of these extremely poor households represents a reduction in severe poverty.

Importantly, for the evaluation performed in this study minimum wages in China were subject to large and heterogeneous local variation. Our empirical analysis focuses on the years 2002-2009 for which the urban household data is available as a stratified panel and can be matched with county-level minimum wage data. During this period, $79.5 \%$ of all county-year events increased their minimum wage in a given year, this translates in 13,874 episodes of minimum wage increases in Chinese counties over the period and is the main source of variation the study exploits. Figure 1 presents a diagram with the annual share of counties and cities that change the nominal minimum wage in the range of 0-20\% or more than 20\%. During the period almost one quarter of China's 2,183 counties and 285 cities in the sample raised the nominal minimum wage by more than $20 \%$. At the same time none of the counties featured a decrease in the nominal wage, local inflation combined with a constant minimum wage can however decrease the real wage, and from 2002 to 2009 an average of $20.5 \%$ (3590) county-year events had nominal minimum wage constant implying a worsening of purchasing power of minimum wage workers. Yet, most local authorities appear attentive to the erosion of the minimum wage by inflation and tend to adjust the minimum wage by more than the rise in consumer prices: of the 13,874 county-year events with a minimum wage increase, only 1,235 had minimum wage increases below the inflation rate in the county. ${ }^{8}$

A final issue concerns the persistence of real minimum wage changes. Even if nominal minimum wage change are unlike to be reversed, inflation can induce the mean reversion of the real minimum wage. If, on the other hand, real minimum wages feature a high degree of persistence, then a raise in the minimum wage corresponds to a permanent income increase. In the following exercise we test the persistent behavior of the real minimum wage with a simple variant of a panel unit root test for the

data on growth are from the World Bank World Development Indicators, productivity data are from the OECD.stat Productivity Archives.

${ }^{8}$ In real terms, approximately half of county-year increases implied a real minimum wage change in the range $0-10 \%$, one-third of minimum wage increases was in the range $10-20 \%$, and only a tenth above $20 \%$. 
mean reverting behavior, we run the following regression:

$$
\Delta M W_{c, t}=\alpha_{0}+\rho M W_{c, t-1}+a_{1} t+\gamma_{c}+\delta_{p, t}+\varepsilon_{c, t}
$$

where a coefficient $\rho<0$ captures mean reversion to a time trend $t$ of the real minimum wage MW, $\gamma_{c}$ denotes a county fixed effect and $\delta_{p t}$ a province-year fixed effect.

Table 2 shows the results of the regression for two periods, namely 1998-2010 and the shorter 20022009 , the latter period corresponds with subsequent empirical analysis. The coefficient of interest $\rho$ is in general negative and statistically significant; nevertheless the magnitude of the mean reversion is economically weak and close to zero. The results show that real minimum wage changes are in general very persistent and can be considered as permanent. ${ }^{9}$

Generally, county-level changes in the real minimum wage are very difficult to predict so that minimum wage change can be interpreted as an unanticipated income effect. Appendix A shows that the decision to change the minimum wage is not predicted by standard socio-economic and political determinants. In conclusion, the high persistence and low predictability of the minimum wage change imply that minimum wage changes in Chinese cities and counties are akin to unanticipated permanent income shocks to low income households. This allows us to interpret the resulting consumption response of households as a test of the permanent income hypothesis. ${ }^{10}$

\subsection{China's Urban Household Survey}

China's Urban Households Survey (UHS) represents a comprehensive and representative survey of urban workers and households managed by the Chinese National Bureau of Statistics (NBS). The UHS is conducted via stratified randomization sampling, records a wide range of demographic and socioeconomic conditions of Chinese urban households, including detailed information on different income sources, wages and granular consumption items for households. In this paper, we restrict our analysis to eight consecutive years of the UHS from 2002 to 2009. Prior to 2002, the survey does not provide a panel structure and we exclude the earlier years from the econometric analysis. We then merge the urban household survey with the minimum wage data. Appendix B provides a detailed

\footnotetext{
${ }^{9}$ We undertake two more panel unit root tests to corroborate the findings. Since our panel has a large cross section and a short time dimension, we first apply the Harris and Tzavalis (1999) test which assumes a fixed time dimension and provides a test with well-behaved size and power properties if the panel dimension is greater than 25 . This test assumes that the autoregressive term is common to all counties, $\rho=\rho_{c}$. In a further approach we use the Im et al. (2003) tests, which relaxes the assumption about the common autoregressive coefficient. The null hypothesis in both tests is that all panels contain a unit root, i.e. the minimum wage is not reverting to the mean. Both tests are one-sided, and in our results they fail to reject the null hypothesis when a trend is included in the auxiliary regressions. The Im et al. (2003) test fails to reject also when we demean the series to reduce the influence of cross-section dependence; the Harris and Tzavalis (1999) test rejects the null hypothesis in this case.

${ }^{10}$ There is a vast literature testing the validity rather than the failure of the permanent income hypothesis in different setting and countries, exploring the reasons for this failure like for example liquidity constraints. The review of this literature is beyond the scope of this paper, however the interested reader can refer to the excellent review by Jappelli and Pistaferri (2010).
} 
description of the merged sample and the data filters applied.

To analyze the impact of minimum wages on household consumption, we divide households in terms of their reliance on wage income near the local minimum wage. Let the variable $S$ denote the share of total non-property income earned by the two best-paid household members due to a wage near the minimum wage. ${ }^{11}$ Labor income of any household member is considered to be near the local minimum wage and counted towards the nominator of $S$ if it falls within the range $50 \%-150 \%$ of the county minimum wage. We calculate the share $S$ for the first year a household enters the survey to limit any endogenous selection effect. ${ }^{12}$ We include in the sample households that have been surveyed for at least two years and that have at least two household members observed in each survey. Formally, let $E_{m, h, c}$ denote the annual labor income and $w_{m, h, c}$ the wage of the two best paid household members $m=1,2$ in household $h$ in county $c$. For a dummy variable $D[]=$.1 indicating a wage in the range $50 \%-150 \%$ of county minimum wage $M W_{c}$, we define minimum wage income share as

$$
S_{h, c}=\frac{1}{\text { Total Income }} \text { I }, c_{m=1,2} E_{m, h, c} \times D\left[0.5 M W_{c} \leq w_{m, h, c} \leq 1.5 M W_{c}\right]
$$

where Total Income $_{h, c}$ in the denominator represents the sum of the total disposable income of the two top earners in the household. ${ }^{13}$ By definition, the minimum wage income share $S_{h c}$ is between 0 and 1; a higher share implies that the household tends to be poorer and more subject to any variation in the minimum wage. In the case where both the household head and spouse work at the minimum wage, the share $S$ approaches one. ${ }^{14}$ Throughout our analysis, we consider households without any minimum wage income $(S=0)$, the complementary set of households with at least some income related to the minimum wage $(S>0)$, households with at least half of their income from wages near the minimum wage $(S>0.5)$, and households very dependent on the minimum wage for their subsistence $(S>0.75)$. The last two groups are the focus of our interest and we can expect the consumption response to minimum wage changes to be most pronounced here.

It is instructive to compare household characteristics across the four different household groups $(S=0, S>0, S>0.5$ and $S>0.75)$ that vary their dependence on minimum wage income. Table A4 in Appendix B reports the differences in the structure of household income and spending and Table A5 the differences in demographic structure.

\footnotetext{
${ }^{11}$ See Aaronson et al. (2012) for a similar definition.

${ }^{12}$ The upper bound of $150 \%$ is consistent with the findings of spillover/ripple effects of minimum wages on the wage distribution whereby workers earning just above the minimum wage tend to have an upgrade when the minimum wage is increased, Krueger and Card (1995). The results are robust to other thresholds for minimum wage worker ripple effect (0.5-1.2 and 0.5-1.3) and to other definitions of the treatment, that is whether or not we assign the treatment in the first year a person is sampled or, alternatively, we allow for assignment to treatment only if the worker earns a minimum wage in every year is observed.

${ }^{13}$ This is composed by the sum of labor income, property income, operating income and transfer income.

${ }^{14}$ If all members of the household are unemployed in the first year the household enters the panel, the sum of the "best" two earners results in a zero labor income and consequently $S=0$. We eliminate these households from the data set (166 observations or $0.2 \%$ of the overall sample) to avoid any confounding effects with households earning labor income above the minimum wage.
} 
Households with $S>0.5(S>0.75)$ account for $6 \%(5 \%)$ of all observations, but earn only $2.6 \%(2.4 \%)$ of all labor income, whereas households without minimum wage income represent $72 \%$ of the sample and earn $81.9 \%$ of all labor income. Generally, poorer households (with $S>0.5$ or $S>0.75)$ feature a lower share of disposable income earned from labor income and rely more on social transfer income from the authorities; almost $20 \%$ of their disposable income comes from social transfers. Moreover, minimum wage dependent households tend to consume a higher proportion of their disposable income (82\%) compared to other households with $S=0(70 \%) \cdot{ }^{15}$

In terms of demographic characteristics, minimum wage households tend to be only slightly larger with 3.3 members compared to 3.1 for the household $S=0$, this fact suggests that the one child policy was implemented consistently across income groups. Unsurprisingly, minimum wage household show lower house ownership rates and their migration to the urban area is typically more recent. We also highlight that minimum wage dependent households are much less likely to work for state-owned enterprise (SOE), these tend to pay higher wages than the private sector. Finally, the educational level and work experience of the head of household tends to be lower for minimum wage dependent families.

\section{Research Design}

\subsection{Is There a Correlation Between Consumption and Minimum Wage Changes?}

Before we explore the link between the consumption of minimum wage dependent households and minimum wage level, it is useful to establish that minimum wages and consumption correlate only for minimum wage dependent households. Omitted variables could potentially influence both the minimum wage level and also the consumptions of households without any minimum wage income. Under such a general correlation, we could not consider the minimum wage as a truly independent variable in the subsequent panel analysis. Next we explore an event study to test the exogeneity of the minimum wage with respect to consumption in a simple two-step procedure.

First, we generate residuals which identify if the minimum wage level is high relative to the province average, in a first-stage regression of the county-level real minimum wage $M W_{c t}$ in year $t$ on a set of interacted province fixed effects $D_{\text {Province }}$ and year fixed effects $D_{\text {Year }}$. Formally,

$$
M W_{c, t}=\alpha_{0}+\alpha_{1}\left[D_{\text {Province }} \times D_{Y e a r}\right]+u_{c, t},
$$

where the residuals $u_{c, t}$ identify the real minimum wage level in a county relative to the province

\footnotetext{
${ }^{15}$ In Table A4 and throughout the analysis, consumption is defined as expenditure on: food, clothes, household services, medical care, education, transportation and living. This is consumption net of purchasing property, transfer expenditures, social contributions and personal social expenditure. It is also net of investments, these can be confounded as savings.
} 
average. The residual value is positive (negative) if a county has a minimum wage level higher (lower) than the average minimum wage level in its province for a given year. In a second step, we fit household consumption change with the residual county changes $\Delta u_{c, t}$, if there is a poitive correlation between the minimum wage change and consumption this should appear only for households depending on minimum wages. To visually inspect this fit we sort the residual county changes $\Delta u_{c, t}$ into bins $b$ of 40 counties and calculate the bin average $\Delta u_{b}$ for each bin $b$. Accordingly, we calculate for all counties in each bin, the corresponding average changes of household consumption $\Delta C_{b}$. In this aggregation, we distinguish minimum wage dependent households $(S>0.5)$ from those without minimum wage income $(S=0)$ and therefore averaging within the bins yields average consumption changes $\Delta C_{b}^{S>0.5}$ and $\Delta C_{b}^{S=0}$. Note that, within a bin, the two groups of households share the common minimum wage change $\Delta u_{b}$ relative to the province-level average. Figure 2 illustrates the binned scatter plots for the two regressions:

$$
\begin{aligned}
\Delta C_{b}^{S>0.5} & =\beta_{0}+\beta_{1} \Delta u_{b}+\epsilon \\
\Delta C_{b}^{S=0} & =\gamma_{0}+\gamma_{1} \Delta u_{b}+\epsilon
\end{aligned}
$$

where the exogeneity test of the event analysis requires $\beta_{1}>0$ and $\gamma_{1}=0$. Consumption changes $\Delta C_{b}^{S=0}$ for non-minimum wage households show a correlation of -0.03 with the relative minimum wage change $\Delta u_{b}$, whereas minimum wage dependent households show a positive correlation of 1.42 . A standard $t$-test for the statistical difference of the two slopes produces a $t$-statistic of 1.56 . Despite the weak statistical significance, it can be inferred from the scatter plot that minimum wage increases are indeed associated with higher household consumption for minimum wage dependent households.

A further refinement of the procedure distinguishes two subsamples: (i) counties in which the nominal minimum wage was constant from one year to another, (ii) those where local authorities implemented nominal minimum wage hikes. In the former case, the county minimum wage decreases with respect to the province-year average, whereas in the latter case the county minimum wages increase relative to the province average. The implications for household consumption differ in the two subsets: only in counties with minimum wage hikes we expect a positive relationship $\left(\beta_{1}>0\right)$ between minimum-wage-household consumption changes and the relative minimum wage change. In Figure 3, we compare the regression lines for cases (i) and (ii) and confirm the conjectured relationship. Only counties with local minimum wage increases have a strong correlation between minimum-wagehouseholds consumption change and the residual change $\Delta u_{b}$. Minimum-wage-households show no consumption changes in counties where the nominal minimum wage was constant.

Figures 2 and 3 provide evidence against any general endogeneity of the minimum wage change with respect to consumption changes. Only in counties with local minimum wage hikes we find a positive correlation with household consumption and this correlation pertains only to minimum wage 
dependent households.

\subsection{Panel Data Methods}

The large spatial and intertemporal variation of minimum wages across Chinese counties suggest a panel analysis to identify and estimate consumption elasticity to minimum wage income shocks. The difference in difference specification compares household consumption across counties with different minimum wage levels, with households in counties with unchanged minimum wage acting as a control group. In light of the heterogeneous household exposure to minimum wage income, we segment the household sample into groups according to their share $S$ of total income received from minimum wage labor. Households without any minimum wage related income $(S=0)$ represent an additional control group relative to those household with $S>0.5(S>0.75)$ which earn more than $50 \%(75 \%)$ of their total income from minimum wages. The household's minimum wage dependence thus constitutes the third dimension of differencing.

The household survey data provide a rich set of demographic and socio-economic characteristics $\left(\boldsymbol{X}_{m, h, t}\right)$ for the two main labor income earners $(m=1,2)$ in the households. For the purpose of the analysis, we use as controls their age and age squared, gender, years of work experience and work experience squared, years since migration to the city and its squared value. Additional categorical covariates include marital status, level of education, occupation and industry of occupation. The observed household characteristics $\left(\boldsymbol{X}_{h, t}\right)$ include family size measured by the number of family members and a house ownership dummy. Apart from labor income, we also observe a household's transfer income, net operating income from business, lending activity and income from property. At the city level, we dispose of a variety of macroeconomic variable $\left(\boldsymbol{X}_{c i t y, t}\right)$ : population size, city real GDP, city real average wage and city unemployment rate. These variables are not available at the more granular county level. But we generally allow for different growth trends at the county level including the interaction of a county dummy and a time trend $\left(\phi_{c} \cdot t\right)$ in the regression. The general specification of the household consumption equation take the reduced form:

$$
C_{h, c, t}=\alpha+\beta^{R F} M W_{c, t}+\boldsymbol{X}_{m, h, t} \boldsymbol{\Lambda}+\boldsymbol{X}_{h, t} \Theta+\boldsymbol{X}_{c i t y, t} \Xi+\phi_{c} \cdot t+\eta_{h}+\delta_{p, t}+\varepsilon_{h, c, t},
$$

where the subscript $h$ characterizes the household, $c$ the county and $t$ the year. The specification also accounts for household fixed effects $\eta_{h}$ and province-year fixed effects $\delta_{p, t}$ to allow for heterogeneous economic developments across China's main geographic regions. All monetary variables, including the minimum wage, are defined in real terms using the province-level consumer price index. The coefficient of interest in this reduced form specification is the linear effect $\beta^{R F}$ of the minimum wage level $M W_{c t}$ on household consumption $C_{h, c, t}$.

A more general approach consists relates household consumption to household income by using 
the minimum wage change as an instrument to explain variation in household income. This two-stage least square estimation (2SLS) first explains household labor income using a first-stage regression

$$
\text { Income }_{h, c, t}=\alpha+\beta^{F S} M W_{c, t}+\boldsymbol{X}_{m, h, t} \boldsymbol{\Lambda}+\boldsymbol{X}_{h, t} \Theta+\boldsymbol{X}_{c i t y, t} \Xi+\phi_{c} \cdot t+\eta_{h}+\delta_{p, t}+\varepsilon_{h, c, t},
$$

and in the second stage relates the predicted income variation $\widehat{\operatorname{Incom}} e_{h, c, t}$ induced by minimum wage variation to account for household consumption, therefore

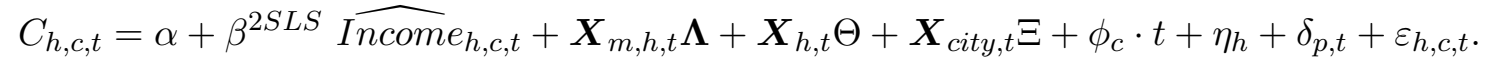

The advantage of the 2SLS approach is that it accounts explicitly for the channel through which minimum wages affect consumption. Intuitively, and conditional on covariates, 2SLS retains only the variation in household labor income that is generated by the minimum wage instrument, and thus provides a cleaner estimate of the direct impact induced by the minimum wage change, Angrist and Pischke (2008). The large and frequent variation of the real minimum wage in China guarantees that the explanatory power of the first-stage regression is sufficiently large.

The first-stage regression can also provide information which component of household income is affected by the minimum wage change. For example minimum wage increases can be accompanied with higher social transfer payment when part of a comprehensive social security benefits policy, so that minimum wage increases also predict increases in social transfers. Alternatively, minimum wage increases can crowd-out transfer income if the latter is subject to eligibility requirements that can - inter alia - depend on the higher labor income. In both cases the impact of the minimum wage on consumption can be biased if transfers are not included in the specification, empirical evidence shows the importance of social security benefit programs in helping poorer families smooth their consumption, Romer and Romer (2016). To control for the complementarity of minimum wage hikes with other social transfer policies a set of specifications cumulates labor and transfer income in a single dependent variable in the first stage regression. ${ }^{16}$

The inclusion of county-level time trends $\phi_{c} \cdot t$ is important for our specification, because we do not dispose of macroeconomic controls at the county level. If we do not allow for county-specific heterogeneous trend growth, the real minimum wage level $M W_{c, t}$ represents the only county level regressor and is likely to subsume county-level heterogeneity and bias the inference. It is straightforward to illustrate this specification issue by comparing first-stage income regressions with and without county time trends; the results are shown in the Appendix Table A6. In the standard two-way specification with only time fixed effects, but without county time trends and interacted province-year fixed effects, the correlation between the real minimum wage and household income is highly significant even for the

\footnotetext{
${ }^{16}$ Transfers are intended net of pension or retirement benefits, our measure of net transfers includes: social assistance income, dismissal compensation, income insurance, income from donations and other transfer income.
} 
household groups not earning any minimum wage income $(S=0)$ as shown in Column (1) of Table A6. By contrast, county time trends in Columns (5)-(8) in combination with province-year fixed effects capture unobserved heterogeneity in the economic development across counties and eliminate any consumption dependence of high income households on the level of the minimum wage. As a consequence of this result, we always present estimates including both linear county trends and province-time fixed effects.

\section{Main Results}

\subsection{First-Stage Income Regressions}

Table 3 presents estimates for the first stage regression for different definitions of household income. We distinguish pure labor income in Columns (1)-(3), transfer income in Columns (4)-(6) and the sum of labor and transfer income in Columns (7)-(9) as the dependent variables. We consider three household groups: those that receive at least $25 \%(S>0.25)$, at least $50 \%(S>0.5)$, or at least $75 \%(S>0.75)$ of their total income from minimum wages, respectively. All specifications include county trends and province-year fixed effects to account for unobserved heterogeneity. We also report three different types of standard errors: two-way clustering at county and province-year levels, and two way-clustering at county and city-year levels. ${ }^{17}$

The effect of minimum wages on labor income in Columns (1)-(3) increases in the minimum wage share $S$ and is significant only for households earning more than half of their disposable income from minimum wages. The coefficient of 1.56 in Column (3) suggests that income elasticity is larger than one for households with a strong minimum wage dependence, this can be explained by the presence of multiple minimum wage earners in the same household. Given the standard error of 0.743 , the t-statistic is 2.104 and in principle is a sign of a sufficiently strong instrument. ${ }^{18}$ More surprising is the large positive predictive effect that minimum wages have for transfer income in the same household group. A positive coefficient of 1.09 in Column (6) implies that a RMB 1,000 increase in the annual minimum wage comes with an equally large increase in social transfers. Accordingly, we find much larger coefficients for the minimum wage effect on the combined labor and transfer income of households. The total household income effect of minimum wage changes is roughly 2.5 times the variation in the annual minimum wage at the county level. With a county clustered standard error of 0.729 the t-statistic approaches the value of 3 , which with a single endogenous variable and single instrument translates in an F-statistics close to 10, hence the instrument relevance of the minimum

\footnotetext{
${ }^{17}$ Two-way clustered standard error allow for arbitrary correlation of residuals due to city/province-wide shocks such as floods, earthquakes or city/province-wide economic policies.

${ }^{18}$ Note further that a single instrument 2SLS is median-unbiased and hence less prone to weak instrument critique, Angrist and Pischke (2008). A more formal test of the validity and relevance of first stage instruments is from Kleibergen and Paap (2006) and is provided in the 2SLS regressions in Table 5.
} 
wage is stronger when used for the sum of labor and transfer incomes as unique endogenous variable. This implies that using the exogenous shift in minimum wage policy as an instrument for income shock will have a greater explanatory power when both labor and transfer incomes are instrumented with minimum wage. It follows that the related 2SLS estimates will be more precisely estimated.

The evidence for transfer income suggests that minimum wage policy in China is one dimension of a more comprehensive set of policy measures targeting low income families. Thus, the minimum wage hike is an instrument for additional changes in social transfers that we do not observe directly, can be interpreted as a social policy measure and proxies for exogenous income effects more generally because it captures local authorities desire to provide transfer income.

\subsection{Reduced Form Regressions}

In this section the reduced form estimates for the relationship between the real minimum wage level and the consumption level in minimum wage dependent households are presented. Table 4 presents two different specifications. First, Columns (1)-(4) report the standard specification adopted in the minimum wage literature on the impact of minimum wages on some outcome of interest, Aaronson et al. (2012), Allegretto et al. (2011) and Neumark et al. (2014a); controls for all non-labor income sources and is related to the first-stage regression with labor income as the dependent variable. Second, Columns (5)-(8) exclude transfer income as a covariate and therefore allow the effect of transfer income on consumption to be captured by the minimum wage change itself. The resulting coefficient is inflated upwards since the minimum wage estimate captures the residual effect of net transfers. The point estimates have increased significantly only for households with $S>0.5$ suggesting that net transfers have a significant contribution in terms of consumption exclusively for households with a higher minimum wage dependence. For them, the relative incidence of net transfers on consumption is substantial given that net transfers constitute less than $8 \%$ of household disposable income, cfr. Table A4 in Appendix B.

In both specifications the point estimate for the annual real minimum wage effect on household consumption increases in the minimum wage share $S$ of household income. For the households most dependent on minimum wage income $(S>0.75)$, the coefficient of interest becomes 2.05 (standard error 0.89) if we control separately for transfer income in Column (4); the estimate increases to 2.52 (standard error 0.88) in Column (8) where the minimum wage simultaneously captures variations in transfer income and its complementary consumption effect.

To evaluate the elasticity of consumption with respect to minimum wage income increases the first specification is preferable. Note that a household consumption elasticity of 2.05 with respect to the annual minimum wage is plausible because consumption is measured at household level while minimum wages are measured at worker level. Households earning more than three-quarters of their total income from minimum wages have both members employed on minimum wages, hence their 
worker level estimate translates in a one to one relation between consumption and the minimum wage increase. ${ }^{19}$

The second specification with its larger coefficient is more appropriate if we want to evaluate the combined policy effect of minimum wage changes and their correlated transfer changes. Here, the minimum wage level proxies not only for the labor market policy in a county, but simultaneously for the level of social transfers. For an evaluation of overall policy variation and its impact on the consumption of low income households, the higher point estimate in the second specification is more informative.

\subsection{Two-Stage Least Square Estimates}

In this section we present two-stage least squares (2SLS) estimates for the effect of minimum wage hikes on consumption. Here, only the part of the minimum wage variation reflected in household income is used to infer the income elasticity of consumption. This may attenuate the role of measurement errors with respect to the minimum wage or its heterogeneous implementation. The 2SLS procedure allows us to operate with different definitions of household income and identify the precise income component through which exogenous policy variation operates. Moreover, since both labor income and consumption are measured at the household level, the 2SLS allows for a more intuitive interpretation of results.

Table 5 presents the 2SLS estimates explaining household consumption as a function of real labor income in Columns (1)-(4) and as a function of the sum of labor and transfer income in Columns (5)(8). Consumption elasticity with respect to labor income is more precisely estimated as the minimum wage share $S$ increases and therefore the instrument quality increases in $S$. For households with more than three-quarters of their disposable income earned through minimum wage labor the impact of 1 RMB rise in income increases consumption by $1.31 \mathrm{RMB}$ in Column (4). The standard errors are however relatively large and we cannot exclude an elasticity lower than one. A one-to-one response of consumption to income shocks is consistent with the permanent income hypothesis to the extent that real minimum wage changes are unanticipated by the household and perceived as permanent.

Estimating consumption response as a function of the sum of labor and transfer income yields consumption elasticities closer to unity and smaller standard errors. For minimum wage dependent households with $S>0.75$ in Column (8), the point estimate is 1.02 with a robust standard error of only 0.35. The lower standard errors in Columns (5)-(8) result from higher explanatory power for the minimum wage instrument if we use a more comprehensive definition of income shock. In both sets of specifications, we reject the null hypothesis of irrelevant or weak instrument using the Kleibergen and Paap (2006) test for households earning more than half of their disposable income from minimum wage labor. However, p-values for the weak instrument test are generally lower in Columns (5)-(8).

\footnotetext{
${ }^{19}$ We exclude part-time workers from households, see Appendix B for more details on the data preparation process.
} 
Overall, we infer from the 2SLS estimates that minimum wage dependent households in China fully spend their labor and transfer income changes induced by the minimum wage increase. As these minimum wage income effects tend to be both unanticipated and permanent (see Table 2 and Appendix A1), we can also interpret these results as confirmation of the permanent income hypothesis.

It is also instructive to compare the 2SLS estimates of consumption propensity with analogous OLS estimates reported in Table A7 in Appendix D. The OLS estimates are considerably smaller and range between 0.33 and 0.44 . What can explain this large difference in the 2SLS estimates? First, standard income changes that do not originate from minimum wage variation could generally be more predictable and transitory and therefore subject to more consumption smoothing, which implies lower consumption elasticity. Second, reporting and measurement errors with respect to household income itself can attenuate the OLS estimate. At the same time, such measurement errors are likely to be orthogonal to the minimum wage variation so that 2SLS estimate remains consistent.

\subsection{Health and Education Expenditure}

An extensive economic literature has documented a positive relationship between health and education on the one hand and productivity and long-run income on the other, Mincer, Bloom and Canning (2000). Therefore, health and educational expenditure present a particular interesting item indicative of the welfare of a household and its children. The household survey data allow us to examine these consumption items separately and document their relationship to the minimum wage level. From a public policy perspective, higher consumption of both health and educational expenditure of low income households in China is particularly desirable given the weakness of China's public health system and often costly access to quality education, Chamon and Prasad (2010).

Table 6 reports 2SLS estimates of the household consumption equation for annual real health expenditure in Columns (1)-(3), for real educational expenditure in Columns (4)-(6) and their sum in Columns (7)-(9). As before, we consider household subsamples with a share $S$ of minimum wage income of at least $25 \%(S>0.25), 50 \%(S>0.25)$, or $75 \%(S>0.75)$ of total household income. For households with the highest minimum wage dependence $(S>0.75)$, we find that a RMB 1,000 higher annual minimum wage increases health expenditure by RMB 226 and educational expenditure by RMB 205. Therefore, more than $40 \%$ of any minimum wage increase is spent either on health or education. This result is confirmed in Column (9) which pools health and educational expenditure as a single dependent variable. The standard error is 0.151 and the estimate is significant at $1 \%$ level. Increased health and educational spending represent substantial portion of the overall consumption response to minimum wage increases. The $40 \%$ expenditure share for marginal minimum wage income hike is very large with respect to the much lower $15 \%$ average expenditure share for both health and educational spending combined, see Table A4 in Appendix B.

The estimates show that higher minimum wages are mostly used by relatively poor household to 
compensate for incomplete public provision of health and educational services, Chamon and Prasad (2010). ${ }^{20}$ The large educational expenditure share for additional minimum wage income indicates a strong intergenerational bequest motive with respect to human capital. Educational spending is regarded as an investment into a higher future family income. In the context of the one-child-policy, parental aspirations typically focus on a single child and educational investment in the child may also serve as a retirement insurance for parents.

\section{$5 \quad$ Household Heterogeneity}

\subsection{Liquidity Constraints}

Consumption propensities of incremental disposable income documented in Section 4 could be the result of borrowing constrains, Zeldes (1989), Jappelli and Pistaferri (2010). In a high income growth environment like China, households may expect a life time income which justifies a desired consumption level larger than current disposable income, but borrowing constrains enforce a lower consumption level equal to disposable income. A higher minimum wage alleviates these expenditure constraints and this may explain the high consumption propensity in particular with respect to heath and educational expenditure. Indeed, minimum wage households are inherently liquidity constrained due to their low proceeds from labor and generally a lack of collateral to pledge against a loan, it is then possible that the findings in the previous section are driven by the inability to smooth consumption over time.

If financial constraints contribute higher consumption propensities, we expect financially unconstrained households to feature lower consumption propensities of minimum wage income. We identify three variables proxying for additional financial resources available to some households. First, we define a dummy indicating that the household has property income. Property serves as collateral in credit relationships and may be used to guarantee a loan. In our sample, roughly $14 \%$ of low income households with $S>0.5$ dispose of property income and may therefore be less likely to face borrowing constrains. ${ }^{21}$ Second, we identify households with interest, dividend or insurance income. The respective dummy variable takes on the value one for $7 \%$ of all households with $S>0.5$. Third, we define outright home ownership households if they own a house and do not have to make mortgage payments. Contrary to non-owners or owners with mortgage debt, outright home owners can pledge their property as collateral to obtain loans and smooth consumption behavior over the life-cycle. Yet, ownership rates are extremely high at $76 \%$ even among relatively poor minimum wage households $(S>0.5)$ and the house value may often be so low that even outright ownership does not necessarily

\footnotetext{
${ }^{20}$ In a separate set of regressions we interacted health and education expenditure with the number of children in the household. The estimates show that around $25 \%$ of the combined health and education response to minimum wages comes from households with children. However the interaction terms are not significant at standard confidence levels.

${ }^{21}$ Among households with some income from property, the mean income from property is RMB 2,957 per year, and the median RMB 630. We construct the dummy (=1) if income from property is above the median of RMB 630 per year.
} 
imply access to credit.

Table 7 reports how the three proxies for credit access interact with the consumption propensity in the 2SLS setting. Columns (1)-(3) show how consumption elasticity with respect to labor and transfer income differs from the baseline coefficient when interacted with the property income dummy. Households with property income above the median, and medium $(S>0.5)$ or high $(S>075)$ minimum wage dependency, consume roughly $30 \%$ less of instrumented income variation compared to the majority of households without property income. The effect is significant at $10 \%$ level. Columns (4)-(6) mark minimum wage households with financial assets; but their consumption propensity is not statistically significantly different from other minimum wage dependent households. Finally, outright house ownership reported in Columns (7)-(9) does not appear to matter much for a household's consumption propensity. The coefficient of -0.121 for the interaction term in Column (9) is economically small and again statistically insignificant. Overall, these results do not support the hypothesis that liquidity constrains drive the high consumption propensities found in Section 4.

\subsection{Family Structure}

The large household propensity to spend a higher minimum wage income on education suggests that family structure matters for the consumption behavior. The one-child policy implies a predominance of single child households, in fact the majority of households in our UHS sample have one child (77\%), households with two children represent $14.5 \%$, childless households are $6.5 \%$, and only $2 \%$ of household have more than two children. ${ }^{22}$

The one-child policy is often blamed for an unbalanced gender ratio between girls and boys in China: abortions are practiced more frequently if the fetus is female. This gender imbalance may have consequences for the marriage market, in which competition for brides require young unmarried men to demonstrate wealth and real estate ownership. It has been argued that this marriage motive may generate higher savings rates among households with a male child and in particular with a male child of adult age, Wei and Zhang (2011), Rosenzweig and Zhang (2014).

Table 8 reports the consumption elasticity of income, where labor and transfer income in Columns (1)-(3) is interacted with a dummy for children in the household, in Columns (4)-(6) with a dummy for a male child, and in Columns (7)-(9) with a more restrictive dummy identifying only male children of 24 years of age (adult male child). The 2SLS estimates in Column (3) provide evidence that a high consumption propensity of minimum wage income is related to children in the family. In fact, childless families with the highest minimum wage dependency $(S>0.75)$ show a lower point estimate for consumption elasticity of income and only households with at least one child behave according to

\footnotetext{
${ }^{22}$ Besides simple non-compliance, a series of exceptions to the one-child policy can be highlighted. For instance a time distance of four to six years between two births may provide a justification for two children, rural families can have two children if the first baby is a girl, and further exemptions exist on ethnic and economic considerations, Baochang et al. (2007).
} 
the permanent income hypothesis with an elasticity close to one. ${ }^{23}$ We infer from Column (6) that the male gender of a child makes only an economically small and statistically insignificant difference to consumption behavior. Male children of adult age increase rather than reduce consumption on average, but the estimated effects are statistically indistinguishable from zero.

While children in the family boost the consumption propensity of a household considerably, there is no support for a gender-based saving bias in low income households dependent on minimum wages. Consistently, our identification strategy does not allow us to generalize this finding to wealthier families for which minimum wages do not matter. As aggregate saving rates depend mostly on the saving behavior of middle and high income families, we need to be careful not to extrapolate these findings for low income families to the Chinese macroeconomy as a whole.

\section{Minimum Wages and Employment}

While higher minimum wages clearly increase the labor income of minimum wage dependent households conditional on continued employment, their effect on the likelihood of employment remains a controversial and highly relevant question. Previous research on China has related higher minimum wages to more instances of lay-off based on firm survey data, Huang et al. (2014). But unlike our household survey data, firm based surveys do not track individual workers and therefore cannot address questions on worker turnover rates or prolonged unemployment spells. Welfare implications are very different in these two cases. Transition to a new job of higher labor productivity contributes to more macroeconomic efficiency, while prolonged unemployment involves large welfare costs for the individual worker. Evidence on the latter issue would therefore be more relevant as an objection to an active minimum wage policy.

Table 9 reports worker-level regressions where the dependent variable is the employment dummy equal to one for employed household members, a zero dummy identifies workers within the labor force declaring to be unemployed at the time of the survey. The zero group includes all adult household members who do not earn any income, but excludes those in training (for example university students) and homeworkers. The independent variable is the log of the county real minimum wage. Column (1) considers workers/employees from all households, while Columns (2)-(4) focus on workers in households of various degrees of minimum wage dependency. Columns (5)-(8) focus on the migrant population of workers who arrived in a city less than 10 years ago. The latter groups can be described as more vulnerable and exposed to minimum wage increases, Orrenius and Zavodny (2008). All specifications include worker and province-year fixed effects and we add additional county level trends. Since the

\footnotetext{
${ }^{23}$ In a separate set of regressions we also test for minimum wage effects on consumption in the one-child household group and compare one-child households to households without children. The estimated interaction coefficient for the dummy for one child is larger than the generic dummy for children in Table 8. Moreover, we compare one-child households with multiple children households to see if the one-child saving motive holds; yet we do not find significantly different consumption responses across these household groups.
} 
migrant population has few observations and due to the large number of fixed effects we consider minimum wage dependent households with more than $20 \%, 40 \%$ or $60 \%$ of total income coming from minimum wages in Columns (6)-(8).

Columns (1)-(4) show increasingly negative point estimates for the real minimum wage for more minimum wage dependent households. Households with the highest minimum wage dependency in Column (4) feature a coefficient of -0.076 : a $10 \%$ real minimum wage hike decreases the likelihood of employment by less than $0.8 \%$. The coefficient is economically and statistically insignificant. The standard error on the coefficient is nevertheless small at 0.057 , which implies that we can exclude large adverse effects of minimum wages on the unemployment risk of a worker. The employment regressions for migrant workers in Columns (5)-(8) produce a somewhat more negative impact of the minimum wage level on employment. For minimum wage dependent migrant households with $S>0.2$ in Column (6), the point estimate for the (log) minimum wage effect on unemployment risk is -0.081 , which implies that a $10 \%$ larger minimum wage increases the risk of unemployment by 0.81 percentage points. In other words, less than one in a hundred migrant workers will suffer unemployment as a consequence of the $10 \%$ higher minimum wage. Moreover, we cannot reject the hypothesis that the total unemployment effect is zero. ${ }^{24}$

One interpretation of these findings is that the level of minimum wages in China, set at around $20 \%$ of the median wage, is low by international standards and has little bite except perhaps the most inefficient employment. Under these circumstances, minimum wage hikes may contribute to labor reallocation without triggering significant unemployment risk for low wage workers. To test this reallocation effect we can examine the relationship between minimum wage level and job switching by defining an occupation switching dummy $(0 / 1)$ for years in which the worker changed occupation. We construct the occupation dummy equal to 1 if the worker has changed occupation from the previous year and zero otherwise.

Table 10 reports employment switching regressions as a function of the minimum wage level. Columns (1)-(4) are based on the sample of all workers in households of different minimum wage dependency $S$ whereas Columns (5)-(8) focus only on migrant workers. We use here the full sample of all migrants and not only the recent flow of immigrants to maximize statistical power through sample size. ${ }^{25}$ Workers in the most minimum wage dependent households in Columns (4) with $S>0.75$ show higher rates of employer switching for a higher minimum wage. The wage coefficient is positive at 0.208 for these minimum wage dependent households compared to only 0.067 for all households. However,

\footnotetext{
${ }^{24}$ All regressions are performed using linear OLS. Non-linear binary dependent variable models are computationally difficult due to the high dimensionality of fixed effects included in the specification. We perform further robustness tests of these finding using county or household level fixed effect: the goodness of fit of these estimates is considerably lower while the point estimates have similar magnitudes. Moreover, we run aggregate regressions using a distinct separate county-level dataset on unemployment rate and obtain a point estimate of -0.064 with a standard error of 0.087 for $S>0.75$.

${ }^{25}$ In a separate set of robustness estimates we drop sequentially the fixed effects and the county trends from the regression and obtain similar results to those in Table 10.
} 
the standard errors are too large to confirm a positive effect at conventional levels of confidence. For migrant workers in Columns (8) the wage coefficient is larger at 0.656, but still statistically insignificant.

Notwithstanding the absence of statistical significance, a larger rate of job reallocation under the higher minimum wage represents a plausible hypothesis that could explain why we find no strong effect of higher minimum wages on the risk of unemployment. Instead, higher minimum wages at the very low minimum wage bite observed in China appear to nudge workers into more productive work in a different occupation.

\section{Robustness: Parallel Trends}

The difference-in-difference estimation requires the parallel (common) trend assumption holds, whereby the outcome variable in the treatment and control group should exhibit similar trends before treatment occurs, and these trends persist in the absence of treatment. Anticipation effects of policy change or diverging pre-existing trend can bias the inference. We therefore seek to show a high degree of synchronization between consumption changes and minimum wage changes.

To validate our research design, we nest household consumption in a more general specification, this allows for asynchronous effects in a two year window around the implementation of the minimum wage change. Formally, we estimate the augmented reduced form

$$
C_{h, c, t}=\alpha+\sum_{k=-2}^{+2} \beta_{k}^{R F} M W_{c, t+k}+\boldsymbol{X}_{m, h, t} \boldsymbol{\Lambda}+\boldsymbol{X}_{h, t} \Theta+\boldsymbol{X}_{c i t y, t} \Xi+\phi_{c} \cdot t+\eta_{h}+\delta_{p, t}+\varepsilon_{h, c, t},
$$

where the parameter of interest $\beta_{k}^{R F}$ takes on different time subscripts to capture a delayed or earlier consumption response relative to the date of minimum wage changes, where we use alternatively time lags of $k=-1,-2$ years or time leads of $k=+1,+2$ years. The lag and lead coefficients are like placebo events for which we conjecture a zero consumption response, hence $\beta_{t}^{R F}=0$ for $t \neq 0$. By including county linear time trends in the regression, $\phi_{c^{*}}$, our identification relies on a sharp contemporaneous relationship between variation of consumption and minimum wage variation, attempting to control for any confounding county trends.

Table A8 in Appendix E reports the augmented specification. Columns (1)-(4) presents consumption elasticity estimates for two periods of lagged response $(k=-1,-2)$, and Columns (5)-(8) for two periods of lead response $(k=+1,+2)$, the latter nest any anticipation effect for the minimum wage increase. In both specifications the contemporaneous response is positive, statistically significant, and consistent with the findings in Section 4. By contrast, the first lag and lead of the minimum wage have a negative sign and are statistically insignificant; neither do the second lag or lead matter from a statistical point of view. We therefore find no evidence for policy anticipation effects on 
household consumption or for persistent effects over time; instead the consumption response occurs contemporaneously to the minimum wage change.

\section{Conclusion}

In the first decade of the new century, China's President Hu Jintao pursued a "harmonious society" policy agenda promising more equity and income equality. But income inequality as measured by the Gini coefficient further increased from 0.45 in 2000 to 0.49 in 2008, placing China at the the top quartile of the world's most unequal economies, Knight (2013), Sicular (2013), Xie and Zhou (2014). Against this general failure of Chinas socio-economic agenda, this paper shows that minimum wage policy and complementary social transfers had a positive impact on the welfare of Chinas low income urban households.

We provide evidence for a positive unit elasticity of consumption to exogenous and permanent income shocks identified by a regulatory change in minimum wages. Increased local minimum wages were often complemented by additional social transfers so that the minimum wage hike underestimates the full income effect for low income households. Higher household incomes were spent in accordance with the permanent income hypothesis, except for households without children which feature higher saving rates. We also find that roughly $40 \%$ of additional minimum wage income was in fact "invested" in health care and educational spending with potential long-term benefits for household welfare. We do not find that higher minimum wages created systematically different patterns of consumption across households deemed more or less financially constrained.

The benefits of higher consumption for the majority of low income households could be challenged if workers faced higher unemployment risk as a consequence of the higher minimum wage. Yet, the household survey data provide no evidence for significant adverse employment effects among the general population and among the more vulnerable migrant population within urban centers. This finding could be explained by the low level of the minimum wage relative to the median wage and a high rate of job turnover, which seems to increase rather than decrease in the minimum wage level. Instead of pricing low-skilled workers out of the market, a higher minimum wage appears to have matched workers to other, perhaps more productive, jobs. The extremely high rates of productivity growth in some firms could have contributed to these particular labor market conditions in China. 


\section{References}

Aaronson, D., Agarwal, S., and French, E. (2012). The spending and debt response to minimum wage hikes. American Economic Review, 102(7):3111-39.

Allegretto, S., Dube, A., Reich, M., and Zipperer, B. (2016). Credible research designs for minimum wage studies: A response to Neumark, Salas and Wascher. Industrial and Labor Relations Review.

Allegretto, S. A., Dube, A., and Reich, M. (2011). Do minimum wages really reduce teen employment? accounting for heterogeneity and selectivity in state panel data. Industrial Relations: A Journal of Economy and Society, 50(2):205-240.

Alonso, C. (2016). Beyond labor market outcomes: The impact of the minimum wage on non durable consumption. Working Paper.

Angrist, J. D. and Pischke, J.-S. (2008). Mostly harmless econometrics: An empiricist's companion. Princeton University Press.

Baochang, G., Feng, W., Zhigang, G., and Erli, Z. (2007). China's local and national fertility policies at the end of the twentieth century. Population and Development Review, 33(1):129-148.

Bloom, D. E. and Canning, D. (2000). The health and wealth of nations. Science, 287(5456):1207-1209.

Bosch, M. and Manacorda, M. (2010). Minimum wages and earnings inequality in urban Mexico. American Economic Journal: Applied Economics, 2(4):128-149.

Card, D. and Krueger, A. B. (2000). Minimum wages and employment: a case study of the fast-food industry in New Jersey and Pennsylvania: reply. The American Economic Review, 90(5):1397-1420.

Chamon, M. D. and Prasad, E. S. (2010). Why are saving rates of urban households in China rising? American Economic Journal: Macroeconomics, pages 93-130.

Comola, M. and De Mello, L. (2011). How does decentralized minimum wage setting affect employment and informality? The case of Indonesia. Review of Income and Wealth, 57(s1):S79-S99.

Deaton, A. (1997). The analysis of household surveys: a microeconometric approach to development policy. World Bank Publications.

Deaton, A. and Grosh, M. (2000). Consumption in designing household survey questionnaires for developing countries. Designing Household Survey Questionnaires for Developing Countries: Lessons from from 15 Years of the Living Standards Measurement Study, 15.

Dickens, R. (2015). How are minimum wages set? IZA World of Labor. 
Du, Y. and Wang, M. (2008). The implementation of minimum wage system and its effects in China. Journal of Graduate School of Chinese Academy of Social Sciences, 6:56-62.

Dube, A., Lester, T. W., and Reich, M. (2010). Minimum wage effects across state borders: Estimates using contiguous counties. The Review of Economics and Statistics, 92(4):945-964.

Engbom, N. and Moser, C. (2016). Earnings inequality and the minimum wage: Evidence from Brazil. Working Paper.

Fang, T. and Lin, C. (2015). Minimum wages and employment in China. IZA Journal of Labor Policy, $4(1): 1-30$.

Harris, R. D. and Tzavalis, E. (1999). Inference for unit roots in dynamic panels where the time dimension is fixed. Journal of Econometrics, 91(2):201-226.

Huang, Y., Loungani, P., and Wang, G. (2014). Minimum wages and firm employment: evidence from China. Available at SSRN 2427606.

Im, K. S., Pesaran, M. H., and Shin, Y. (2003). Testing for unit roots in heterogeneous panels. Journal of Econometrics, 115(1):53-74.

Jappelli, T. and Pistaferri, L. (2010). The consumption response to income changes. Annual Review of Economics, 2(1):479-506.

Kleibergen, F. and Paap, R. (2006). Generalized reduced rank tests using the singular value decomposition. Journal of Econometrics, 133(1):97-126.

Knight, J. (2013). Inequality in China: an overview. The World Bank Research Observer.

Krueger, A. B. and Card, D. (1995). Myth and measurement: The new economics of the minimum wage.

Meghir, C., Narita, R., and Robin, J.-M. (2012). Wages and informality in developing countries. Technical report, National Bureau of Economic Research.

Mincer, J. Investment in human capital and personal income distribution. The Journal of Political Economy.

Neumark, D., Salas, J. I., and Wascher, W. (2014a). More on recent evidence on the effects of minimum wages in the United States. IZA Journal of Labor policy, 3(1):1.

Neumark, D., Salas, J. I., and Wascher, W. (2014b). Revisiting the minimum wageemployment debate: Throwing out the baby with the bathwater? Industrial \& Labor Relations Review, 67(3 suppl):608-648. 
Neumark, D. and Wascher, W. (1992). Employment effects of minimum and subminimum wages: panel data on state minimum wage laws. Industrial $\& 3$ Labor Relations Review, 46(1):55-81.

Neumark, D. and Wascher, W. (2011). Does a higher minimum wage enhance the effectiveness of the earned income tax credit? Industrial \& Labor Relations Review, 64(4):712-746.

Orrenius, P. M. and Zavodny, M. (2008). The effect of minimum wages on immigrants' employment and earnings. Industrial \& Labor Relations Review, 61(4):544-563.

Paxson, C. H. Consumption and income seasonality in Thailand. Journal of Political Economy.

Rama, M. (2001). The consequences of doubling the minimum wage: the case of Indonesia. Industrial E Labor Relations Review, 54(4):864-881.

Ravallion, M., Chen, S., and Sangraula, P. (2009). Dollar a day revisited. The World Bank Economic Review.

Rawski, T. G. (2003). Recent developments in China's labour economy. Recent Developments in China's Labour Economy (October, 2003).

Romer, C. D. and Romer, D. H. (2016). Transfer payments and the macroeconomy: The effects of social security benefit increases, 1952-1991. American Economic Journal: Macroeconomics, 8(4):142.

Rosenzweig, M. and Zhang, J. (2014). Co-residence, life-cycle savings and inter-generational support in urban China. Technical report, National Bureau of Economic Research.

Shih, V., Shan, W., and Liu, M. (2010). Gauging the elite political equilibrium in the CCP: a quantitative approach using biographical data. The China Quarterly, 201:79-103.

Sicular, T. (2013). The challenge of high inequality in China. Inequality in Focus, World Bank Publications, 2(2):1-5.

Wei, S.-J. and Zhang, X. (2011). The competitive saving motive: Evidence from rising sex ratios and savings rates in China. Journal of Political Economy, 119(3):511-564.

Wolpin, K. I. A new test of the permanent income hypothesis: the impact of weather on the income and consumption of farm households in India. International Economic Review.

Xie, Y. and Zhou, X. (2014). Income inequality in todays China. Proceedings of the National Academy of Sciences, 111(19):6928-6933.

Yao, Y. and Zhang, M. (2015). Subnational leaders and economic growth: evidence from chinese cities. Journal of Economic Growth, 20(4):405-436. 
Ye, L., Gindling, T., and Li, S. (2015). Compliance with legal minimum wages and overtime pay regulations in China. IZA Journal of Labor \& Development, 4(1):1.

Zeldes, S. P. (1989). Consumption and liquidity constraints: an empirical investigation. The Journal of Political Economy, pages 305-346.

Zhongwei, S. and Binbin, S. (2011). The standard of the minimum wage, and the wages of peasantworkers: a case study based on Zhujiang delta. Management World, 8.

Zhou, T. (2016). The geography of power elites in China: Facts, causes and consequences. PhD Dissertation. 
Figure 1: Minimum Wage Variation

Proportion of counties increasing their nominal minimum wage in China, 1996-2012. We plot by year the percentage of China's 2,183 counties and 285 cities in our sample with a strictly positive minimum wage change between 0 and $10 \%$, between $10 \%$ and $20 \%$, and above $20 \%$, respectively. The column height represents the combined share of counties experiencing an increase of their nominal minimum wage in a given year.

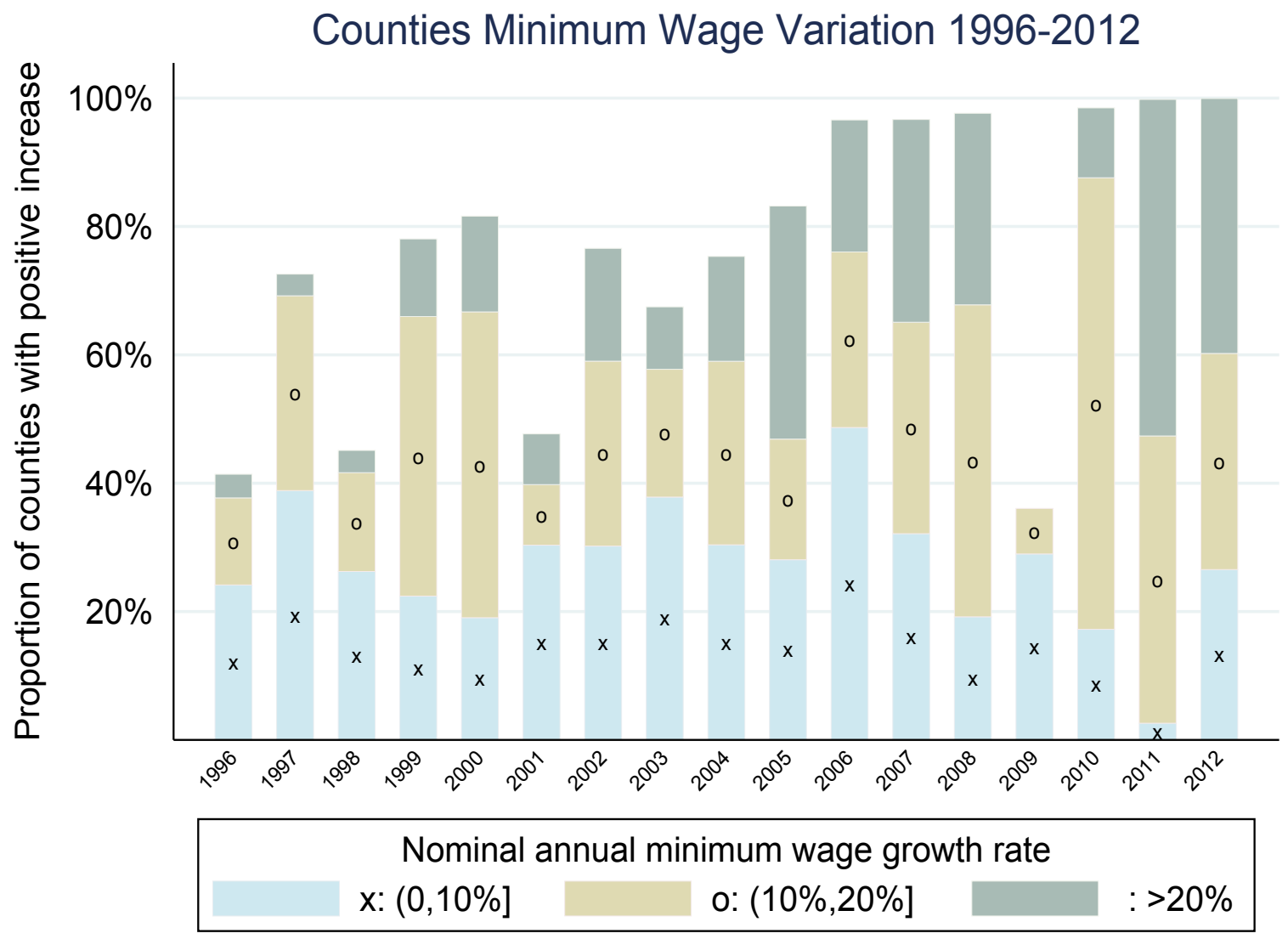


Figure 2: Household Consumption and County Minimum Wages I

Average real consumption changes are plotted for minimum wage dependent households $(S>0.5$, red crosses) and those without minimum wage income $(S=0$, blue dots). We sort all households into 40 bins according to the magnitude of the local real minimum wage increase relative to province-level average minimum wages. The dashed line represents the fitted linear relationship for minimum wage dependent households and the solid line for households without minimum wage income. The source regression has 32,355 household-level observations. A standard $t$-test for the statistical difference of the two slopes produces a $t$-statistic of 1.56

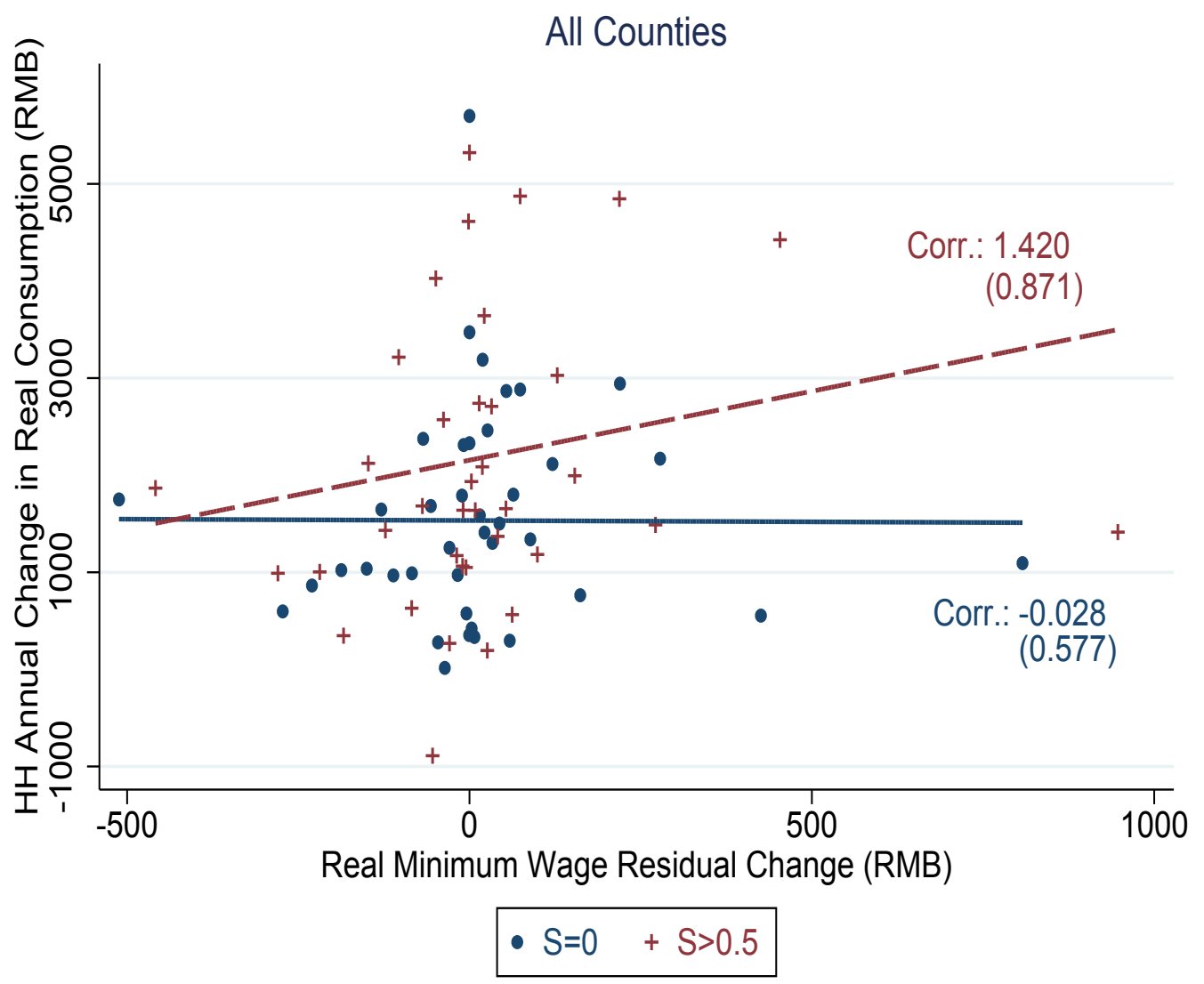


Figure 3: Household Consumption and County Minimum Wages II

After sorting counties into those with and without a nominal minimum wage change in a given year, we proceed as in Figure 2: average real consumption changes are plotted for minimum wage dependent households $(S>0.5$, red crosses) and those without minimum wage income ( $S=0$, blue dots). In each panel households are sorted into 40 bins according to the magnitude of the local real minimum wage increase relative to province-level average minimum wages. The dashed line represents the fitted linear relationship for minimum wage dependent households and the solid line for households without minimum wage income.

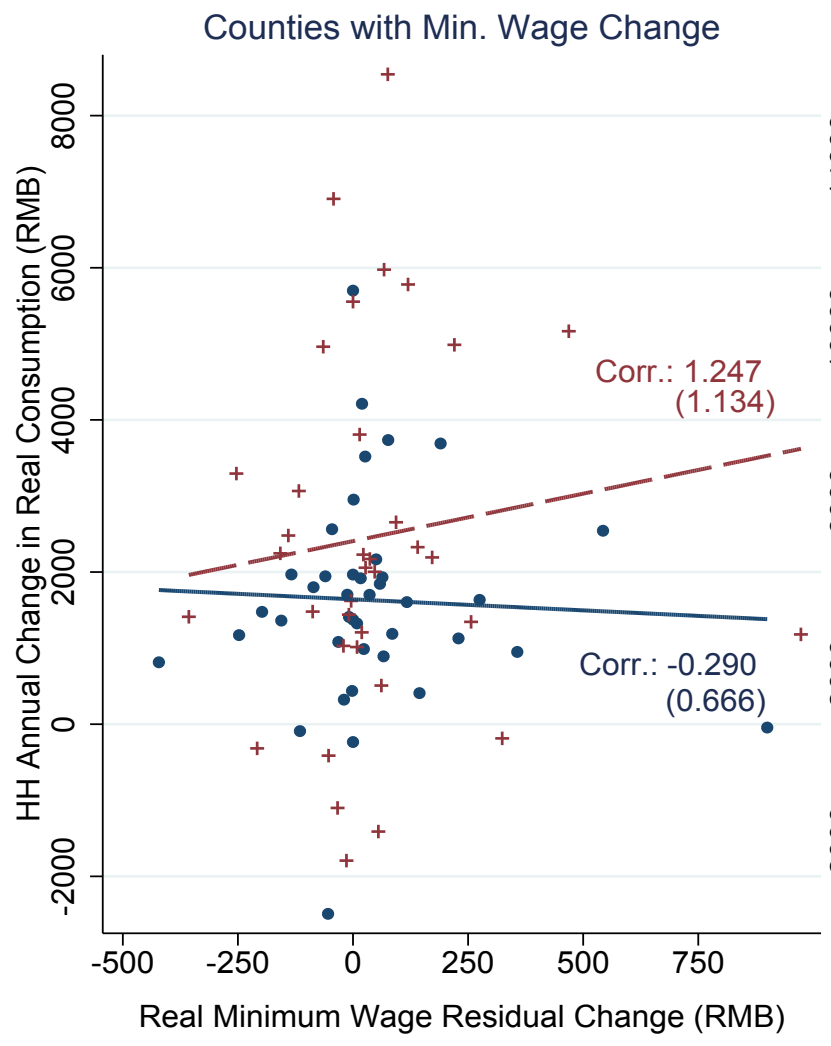

- $S=0+S>0.5$
Counties with No Min. Wage Change

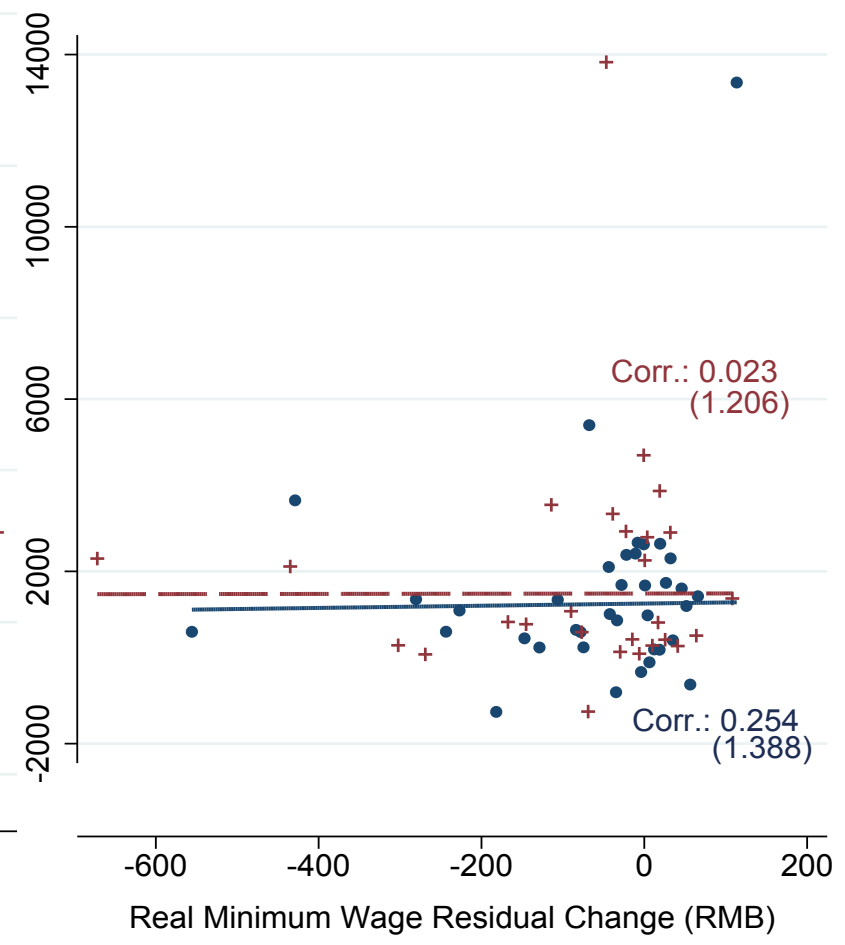

- $S=0+S>0.5$ 
Table 1: Minimum Wage Relative to Median Wage and Minimum Wage Growth

Reported are the average minimum wage bite by year and the annual growth rate of the real minimum wage. The minimum wage bite is computed as the ratio of the minimum wage (MW) to the median wage in each county and then averaged across counties. Standard deviations are provided in parentheses below.

\begin{tabular}{lrrrrrrrr}
\hline Year & 2002 & 2003 & 2004 & 2005 & 2006 & 2007 & 2008 & 2009 \\
\cline { 2 - 8 } & & & & & & & & \\
MW relative to median wage & 0.202 & 0.201 & 0.197 & 0.198 & 0.201 & 0.185 & 0.189 & 0.176 \\
& $(0.042)$ & $(0.043)$ & $(0.046)$ & $(0.045)$ & $(0.045)$ & $(0.045)$ & $(0.053)$ & $(0.045)$ \\
Real MW growth & 12.99 & 7.97 & 8.71 & 12.32 & 7.53 & 8.74 & 8.92 & 8.04 \\
& $(7.71)$ & $(6.24)$ & $(8.17)$ & $(6.96)$ & $(6.83)$ & $(8.07)$ & $(6.11)$ & $(2.61)$ \\
\hline
\end{tabular}

Table 2: Persistence of Real Minimum Wage Shocks

We regress changes in the real minimum wage $\left(\Delta M W_{c t}\right)$ on the lagged real minimum wages $\left(M W_{c t-1}\right)$ controlling for trend growth. The regressions add county or province-year fixed effects as specified in Equation (1). A significant negative coefficient implies reversion of the minimum wage shocks to trend growth. Standard errors clustered at county level are shown in parentheses. Stars ${ }^{* * *},{ }^{* *}$, and ${ }^{*}$ indicate statistical significance at the 1 , 5 , and 10 percent levels, respectively.

\begin{tabular}{|c|c|c|c|c|c|c|}
\hline \multirow[t]{3}{*}{ Dep. variable: } & \multicolumn{6}{|c|}{ Real minimum wage change, $\Delta M W_{c, t}$} \\
\hline & \multicolumn{3}{|c|}{ Period 1998-2010 } & \multicolumn{3}{|c|}{ Period 2002-2009 } \\
\hline & (1) & $(2)$ & $(3)$ & (4) & $(5)$ & $(6)$ \\
\hline$M W_{c, t-1}$ & $\begin{array}{r}-0.033 \\
(0.006)^{* * *}\end{array}$ & $\begin{array}{r}-0.012 \\
(0.004)^{* * *}\end{array}$ & $\begin{array}{r}-0.162 \\
(0.009)^{* * *}\end{array}$ & $\begin{array}{r}-0.047 \\
(0.007)^{* * *}\end{array}$ & $\begin{array}{r}0.012 \\
(0.004)^{* * *}\end{array}$ & $\begin{array}{r}-0.284 \\
(0.013)^{* * *}\end{array}$ \\
\hline County FE & No & No & Yes & No & No & Yes \\
\hline Province $\times$ year FE & No & Yes & Yes & No & Yes & Yes \\
\hline Trend & Yes & Yes & Yes & Yes & Yes & Yes \\
\hline Observations & 22,005 & 22,000 & 22,000 & 11,859 & 11,859 & 11,859 \\
\hline Number of clusters & 1,699 & 1,698 & 1,698 & 1,697 & 1,697 & 1,697 \\
\hline Adjusted $R^{2}$ & 0.072 & 0.841 & 0.861 & 0.020 & 0.836 & 0.875 \\
\hline
\end{tabular}


Table 3: Household Income Sources and the Real Minimum Wage

We regress the levels of household real annual labor income in Columns (1)-(3), transfer income in Columns (4)-(6), and their sum in Column (7)-(9), on the local effective real minimum wage level. The samples consist of all households for which the labor income share $S$ from wages near the minimum wage represents more than $25 \%(S>0.25)$, or more than $50 \%(S>0.5)$, or more than $75 \%(S>0.75)$ of household labor income. All regressions include household, county and interacted province-year fixed effects, city level controls and county time-trends as specified in Equation (7). We report standard errors clustered at county level in parentheses, two-way clustered at county and city-year level in brackets and two-way clustered at county and province-year level in curly brackets. Stars ${ }^{* *},{ }^{* *}$, and ${ }^{*}$ indicate statistical significance at the 1, 5, and 10 percent levels, respectively

\begin{tabular}{|c|c|c|c|c|c|c|c|c|c|}
\hline \multirow{2}{*}{$\begin{array}{l}\text { Dep. variables: } \\
\text { MW dependency: }\end{array}$} & \multicolumn{3}{|c|}{ Household Labor Income } & \multicolumn{3}{|c|}{ Household Transfer Income } & \multicolumn{3}{|c|}{ HH Labor and Transfer Income } \\
\hline & $\begin{array}{c}S>0.25 \\
(1)\end{array}$ & $\begin{array}{c}S>0.5 \\
(2)\end{array}$ & $\begin{array}{c}S>0.75 \\
(3)\end{array}$ & $\begin{array}{c}S>0.25 \\
(4)\end{array}$ & $\begin{array}{c}S>0.5 \\
(5)\end{array}$ & $\begin{array}{c}S>0.75 \\
(6)\end{array}$ & $\begin{array}{c}S>0.25 \\
(7)\end{array}$ & $\begin{array}{c}S>0.5 \\
(8)\end{array}$ & $\begin{array}{c}S>0.75 \\
(9)\end{array}$ \\
\hline Minimum wage & $\begin{array}{r}0.710 \\
(0.522) \\
{[0.540)} \\
\{0.592\}\end{array}$ & $\begin{array}{r}1.378 \\
(0.636)^{* *} \\
{[0.675)^{* *}} \\
\{0.754\}^{*}\end{array}$ & $\begin{array}{r}1.563 \\
(0.743)^{* *} \\
{[0.772]^{* *}} \\
\{0.895\}^{*}\end{array}$ & $\begin{array}{r}0.308 \\
(0.209) \\
{[0.217]} \\
\{0.242\}\end{array}$ & $\begin{array}{r}0.767 \\
(0.567) \\
{[0.575]} \\
\{0.605\}\end{array}$ & $\begin{array}{r}1.091 \\
(0.577)^{*} \\
{[0.581]^{*}} \\
\{0.683\}\end{array}$ & $\begin{array}{r}0.965 \\
(0.581)^{*} \\
{[0.600]} \\
\{0.614\}\end{array}$ & $\begin{array}{r}2.017 \\
(0.729)^{* * *} \\
{[0.754]^{* * *}} \\
\{0.799\}^{* *}\end{array}$ & $\begin{array}{r}2.475 \\
(0.758)^{* * *} \\
{[0.934]^{* * *}} \\
\{0.850\}^{* * *}\end{array}$ \\
\hline $\begin{array}{l}\text { City level controls } \\
\text { Household FE } \\
\text { County trend } \\
\text { Province } \times \text { year FE }\end{array}$ & $\begin{array}{l}\text { Yes } \\
\text { Yes } \\
\text { Yes } \\
\text { Yes }\end{array}$ & $\begin{array}{l}\text { Yes } \\
\text { Yes } \\
\text { Yes } \\
\text { Yes }\end{array}$ & $\begin{array}{l}\text { Yes } \\
\text { Yes } \\
\text { Yes } \\
\text { Yes }\end{array}$ & $\begin{array}{l}\text { Yes } \\
\text { Yes } \\
\text { Yes } \\
\text { Yes }\end{array}$ & $\begin{array}{l}\text { Yes } \\
\text { Yes } \\
\text { Yes } \\
\text { Yes }\end{array}$ & $\begin{array}{l}\text { Yes } \\
\text { Yes } \\
\text { Yes } \\
\text { Yes }\end{array}$ & $\begin{array}{l}\text { Yes } \\
\text { Yes } \\
\text { Yes } \\
\text { Yes }\end{array}$ & $\begin{array}{l}\text { Yes } \\
\text { Yes } \\
\text { Yes } \\
\text { Yes }\end{array}$ & $\begin{array}{l}\text { Yes } \\
\text { Yes } \\
\text { Yes } \\
\text { Yes }\end{array}$ \\
\hline $\begin{array}{l}\text { Observations } \\
\text { Number of clusters } \\
\text { Adjusted } R^{2}\end{array}$ & $\begin{array}{r}14,031 \\
474 \\
0.864\end{array}$ & $\begin{array}{r}4,267 \\
336 \\
0.889\end{array}$ & $\begin{array}{r}3,899 \\
328 \\
0.889\end{array}$ & $\begin{array}{r}14,031 \\
474 \\
0.614\end{array}$ & $\begin{array}{r}4,267 \\
336 \\
0.606\end{array}$ & $\begin{array}{r}3,899 \\
328 \\
0.583\end{array}$ & $\begin{array}{r}14,031 \\
474 \\
0.848\end{array}$ & $\begin{array}{r}4,267 \\
336 \\
0.870\end{array}$ & $\begin{array}{r}3,899 \\
328 \\
0.872\end{array}$ \\
\hline
\end{tabular}


Table 4: Household Consumption and the Minimum Wage

Reduced form specifications regress the annual real household consumption in RMB on the real local minimum wage level where Columns (1)-(4) control for all non-labor income and Columns (5)-(8) for non-labor income without transfer income. The samples consist of all households for which the labor income share $S$ from wages near the minimum wage represent a strictly positive share $(S>0)$, more than $25 \%(S>0.25)$, or more than $50 \%$ $(S>0.5)$, or more than $75 \%(S>0.75)$ of household labor income. All regressions include household, county and interacted province-year fixed effects, city level controls and county time-trends as specified in Equation (6). We report standard errors clustered at county level in parentheses, two-way clustered at county and city-year level in brackets and two-way clustered at county and province-year level in curly brackets. Stars ${ }^{* * *},{ }^{* *}$, and ${ }^{*}$ indicate statistical significance at the 1,5 , and 10 percent levels respectively.

\begin{tabular}{|c|c|c|c|c|c|c|c|c|}
\hline \multirow{2}{*}{$\begin{array}{l}\text { Dep. variable: } \\
\text { MW dependency: }\end{array}$} & \multicolumn{8}{|c|}{ Household Consumption } \\
\hline & $\begin{array}{c}S>0 \\
(1)\end{array}$ & $\begin{array}{c}S>0.25 \\
\quad(2)\end{array}$ & $\begin{array}{c}S>0.5 \\
\quad(3)\end{array}$ & $\begin{array}{c}S>0.75 \\
\quad(4)\end{array}$ & $\begin{array}{c}S>0 \\
(5)\end{array}$ & $\begin{array}{c}S>0.25 \\
\quad(6)\end{array}$ & $\begin{array}{c}S>0.5 \\
\quad(7)\end{array}$ & $\begin{array}{c}S>0.75 \\
\quad(8)\end{array}$ \\
\hline Minimum wage & $\begin{array}{r}0.856 \\
(0.567) \\
{[0.588]} \\
\{0.636\}\end{array}$ & $\begin{array}{r}1.091 \\
(0.561)^{*} \\
{[0.587]^{*}} \\
\{0.623\}^{*}\end{array}$ & $\begin{array}{r}1.786 \\
(0.782)^{* *} \\
{[0.795]^{* *}} \\
\{0.848\}^{* *}\end{array}$ & $\begin{array}{r}2.054 \\
(0.893)^{* *} \\
{[0.907]^{* *}} \\
\{0.987\}^{* *}\end{array}$ & $\begin{array}{r}0.885 \\
(0.575) \\
{[0.599]} \\
\{0.645\}\end{array}$ & $\begin{array}{r}1.184 \\
(0.569)^{* *} \\
{[0.595)^{* *}} \\
\{0.656\}^{*}\end{array}$ & $\begin{array}{r}2.107 \\
(0.829)^{* *} \\
{[0.840]^{* *}} \\
\{0.891\}^{* *}\end{array}$ & $\begin{array}{r}2.515 \\
(0.880)^{* * *} \\
{[0.899]^{* * *}} \\
\{0.925\}^{* * *}\end{array}$ \\
\hline
\end{tabular}

Controls:

\begin{tabular}{|c|c|c|c|c|c|c|c|c|}
\hline All non-labor income & Yes & Yes & Yes & Yes & No & No & No & No \\
\hline $\begin{array}{l}\text { Non-labor income } \\
\text { excluding transfers }\end{array}$ & No & No & No & No & Yes & Yes & Yes & Yes \\
\hline City level controls & Yes & Yes & Yes & Yes & Yes & Yes & Yes & Yes \\
\hline Household FE & Yes & Yes & Yes & Yes & Yes & Yes & Yes & Yes \\
\hline County trend & Yes & Yes & Yes & Yes & Yes & Yes & Yes & Yes \\
\hline Province $\times$ year FE & Yes & Yes & Yes & Yes & Yes & Yes & Yes & Yes \\
\hline Observations & 19,728 & 1,4031 & 4,267 & 3,899 & 19,728 & 14,031 & 4,267 & 3,899 \\
\hline Number of clusters & 508 & 474 & 336 & 328 & 508 & 474 & 336 & 328 \\
\hline Adjusted $R^{2}$ & 0.790 & 0.809 & 0.843 & 0.851 & 0.789 & 0.805 & 0.849 & 0.860 \\
\hline
\end{tabular}


Table 5: Household Consumption under Labor Income Shocks

We report 2SLS level regressions in which real annual household consumption in RMB is alternatively regressed on the household's fitted annual real labor income level in Columns (1)-(4), or the fitted annual real labor income plus transfers level in Columns (5)-(8). The first-stage regressions are reported in Table 2. The samples consist of all households for which the labor income share $S$ from wages near the minimum wage represent a strictly positive share $(S>0)$, more than $25 \%(S>0.25)$, or more than $50 \%(S>0.5)$, or more than $75 \%(S>0.75)$ of household labor income. All regressions include city level controls, household fixed effects, interacted province-year fixed effects, and county time-trends as specified in Equation (8). We report standard errors clustered at county level in parentheses, two-way clustered at county and city-year level in brackets and two-way clustered at county and province-year level in curly brackets. The $p$-values in the last line refer to a test under the null hypothesis of weak instruments (Kleibergen and Paap, 2006). Stars ${ }^{* * *},{ }^{* *}$, and ${ }^{*}$ indicate statistical significance at the 1,5 , and 10 percent levels, respectively.

Dep. variable:

Household Consumption

\begin{tabular}{lrrrr} 
MW dependency: & $S>0$ & $S>0.25$ & $S>0.5$ & $S>0.75$ \\
& $(1)$ & $(2)$ & $(3)$ & $(4)$ \\
\hline & & & & \\
Fitted labor income & 1.687 & 1.538 & 1.296 & 1.314 \\
& $(1.415)$ & $(0.865)^{*}$ & $(0.609)^{* *}$ & $(0.651)^{* *}$ \\
& {$[1.417]$} & {$[0.838]^{*}$} & {$[0.603]^{* *}$} & {$[0.644]^{* *}$} \\
& $\{1.375\}$ & $\{0.863\}^{*}$ & $\{0.572\}^{* *}$ & $\{0.609\}^{* *}$
\end{tabular}

Fitted labor and

transfer income

$\begin{array}{rrrr}1.117 & 1.227 & 1.045 & 1.016 \\ (0.712) & (0.555)^{* *} & (0.375)^{* * *} & (0.363)^{* * *} \\ {[0.707]} & {[0.539]^{* *}} & {[0.363]^{* * *}} & {[0.354]^{* * *}} \\ \{0.693\} & \{0.522\}^{* *} & \{0.370\}^{* * *} & \{0.341\}^{* * *}\end{array}$

\begin{tabular}{|c|c|c|c|c|c|c|c|c|}
\hline City-level controls & Yes & Yes & Yes & Yes & Yes & Yes & Yes & Yes \\
\hline Household FE & Yes & Yes & Yes & Yes & Yes & Yes & Yes & Yes \\
\hline County trend & Yes & Yes & Yes & Yes & Yes & Yes & Yes & Yes \\
\hline Province $\times$ year FE & Yes & Yes & Yes & Yes & Yes & Yes & Yes & Yes \\
\hline Observations & 19,728 & 14,031 & 4,270 & 3,903 & 19,728 & 14,031 & 4,270 & 3,903 \\
\hline Number of clusters & 508 & 474 & 336 & 328 & 508 & 474 & 336 & 328 \\
\hline $\begin{array}{l}H_{0}: \text { Weak instruments } \\
\text { ( } p \text {-value) }\end{array}$ & 0.325 & 0.209 & 0.038 & 0.040 & 0.182 & 0.134 & 0.005 & 0.002 \\
\hline
\end{tabular}


Table 6: Household Health and Education Expenditure under Labor Income Shocks

The 2SLS level regressions of Table 5, Columns (6)-(8) are repeated for subcomponents of household consumption, namely health expenditure in Columns (1)-(3), education expenditure in Columns (4)-(6) and the sum of health and education expenditure in Columns (7)-(9). Stars ${ }^{* * *},{ }^{* *}$, and ${ }^{*}$ indicate statistical significance at the 1, 5, and 10 percent levels, respectively. Standard errors in parenthesis are clustered at county level. Weak instrument row shows the p-value of the Kleibergen and Paap (2006) test under the null of weak instrument.

\begin{tabular}{|c|c|c|c|c|c|c|c|c|c|}
\hline \multirow{2}{*}{$\begin{array}{l}\text { Dep. variables: } \\
\text { MW dependency }\end{array}$} & \multicolumn{3}{|c|}{ Health Expenditure } & \multicolumn{3}{|c|}{ Education Expenditure } & \multicolumn{3}{|c|}{ Health + Education Exp. } \\
\hline & $\begin{array}{c}S>0.25 \\
\quad(1)\end{array}$ & $\begin{array}{c}S>0.5 \\
(2)\end{array}$ & $\begin{array}{c}S>0.75 \\
\quad(3)\end{array}$ & $\begin{array}{c}S>0.25 \\
\quad(4)\end{array}$ & $\begin{array}{c}S>0.5 \\
\quad(5)\end{array}$ & $\begin{array}{l}S>0.75 \\
\quad(6)\end{array}$ & $\begin{array}{c}S>0.25 \\
\quad(7)\end{array}$ & $\begin{array}{c}S>0.5 \\
\quad(8)\end{array}$ & $\begin{array}{c}S>0.75 \\
\quad(9)\end{array}$ \\
\hline $\begin{array}{l}\text { Fitted labor and } \\
\text { transfer income }\end{array}$ & $\begin{array}{l}-0.047 \\
(0.143)\end{array}$ & $\begin{array}{r}0.224 \\
(0.128)^{*}\end{array}$ & $\begin{array}{r}0.226 \\
(0.120)^{*}\end{array}$ & $\begin{array}{r}0.230 \\
(0.196)\end{array}$ & $\begin{array}{r}0.183 \\
(0.146)\end{array}$ & $\begin{array}{r}0.205 \\
(0.133)\end{array}$ & $\begin{array}{r}0.184 \\
(0.209)\end{array}$ & $\begin{array}{r}0.406 \\
(0.164)^{* *}\end{array}$ & $\begin{array}{r}0.431 \\
(0.151)^{* * *}\end{array}$ \\
\hline City-level controls & Yes & Yes & Yes & Yes & Yes & Yes & Yes & Yes & Yes \\
\hline Household FE & Yes & Yes & Yes & Yes & Yes & Yes & Yes & Yes & Yes \\
\hline County trend & Yes & Yes & Yes & Yes & Yes & Yes & Yes & Yes & Yes \\
\hline Province $\times$ year FE & Yes & Yes & Yes & Yes & Yes & Yes & Yes & Yes & Yes \\
\hline Observations & 12,676 & 3,876 & 3,538 & 12,676 & 3,876 & 3,538 & 12,676 & 3,876 & 3,538 \\
\hline Number of clusters & 282 & 238 & 235 & 282 & 238 & 235 & 282 & 238 & 235 \\
\hline $\begin{array}{l}H_{0} \text { : Weak instruments } \\
\text { (p-value) }\end{array}$ & 0.118 & 0.017 & 0.006 & 0.118 & 0.017 & 0.006 & 0.118 & 0.017 & 0.006 \\
\hline
\end{tabular}


Table 7: Household Consumption and Liquidity Constraints

We report 2SLS level regressions in which real annual household consumption is regressed on the household's fitted annual real labor and transfer income and on additional interaction terms identifying liquidity constrained households. The interaction terms are property income dummy in Columns (1)-(3), a capital income dummy for interest, dividends and insurance income in Columns (4)-(6), and a dummy for (debt-free) house ownership in Columns (7)-(9). The samples consist of all households for which the labor income share $S$ from wages near the minimum wage represent a strictly positive share $(S>0)$, more than $25 \%(S>0.25)$, or more than $50 \%$ $(S>0.5)$, or more than $75 \%(S>0.75)$ of household labor income. All regressions include city level controls, household fixed effects, interacted province-year fixed effects, and county time-trends as specified in Equation (8). We report standard errors clustered at county level in parentheses. The $p$-values in the last line refer to a test under the null of weak instruments (Kleibergen and Paap, 2006). Stars ${ }^{* * *},{ }^{* *}$, and ${ }^{*}$ indicate statistical significance at the 1,5 , and 10 percent levels, respectively.

\begin{tabular}{|c|c|c|c|c|c|c|c|c|c|}
\hline \multirow{2}{*}{$\begin{array}{l}\text { Dep. variables: } \\
\text { MW dependency }\end{array}$} & \multicolumn{9}{|c|}{ Household Consumption } \\
\hline & $\begin{array}{c}S>0.25 \\
(1)\end{array}$ & $\begin{array}{c}S>0.5 \\
\quad(2)\end{array}$ & $\begin{array}{c}S>0.75 \\
\quad(3)\end{array}$ & $\begin{array}{c}S>0.25 \\
(4)\end{array}$ & $\begin{array}{c}S>0.5 \\
(5)\end{array}$ & $\begin{array}{c}S>0.75 \\
(6)\end{array}$ & $\begin{array}{c}S>0.25 \\
\quad(7)\end{array}$ & $\begin{array}{c}S>0.5 \\
\quad(8)\end{array}$ & $\begin{array}{c}S>0.75 \\
(9)\end{array}$ \\
\hline $\begin{array}{l}\text { Fitted labor and } \\
\text { transfer income }\end{array}$ & $\begin{array}{r}1.273 \\
(0.658)^{*}\end{array}$ & $\begin{array}{r}1.042 \\
(0.345)^{* * *}\end{array}$ & $\begin{array}{r}1.012 \\
(0.337)^{* * *}\end{array}$ & $\begin{array}{r}1.161 \\
(0.545)^{* *}\end{array}$ & $\begin{array}{r}0.876 \\
(0.398)^{* *}\end{array}$ & $\begin{array}{r}0.921 \\
(0.380)^{* *}\end{array}$ & $\begin{array}{r}1.242 \\
(0.566)^{* *}\end{array}$ & $\begin{array}{r}1.137 \\
(0.444)^{* *}\end{array}$ & $\begin{array}{r}1.135 \\
(0.428)^{* * *}\end{array}$ \\
\hline
\end{tabular}

Fitted labor and transfer income

$\times$ Property income dummy

$\begin{array}{lll}-0.062 & -0.325 & -0.301\end{array}$

$(0.134) \quad(0.164)^{* *} \quad(0.177)^{*}$

Fitted labor and

transfer income

$\times$ Capital income dummy

$\begin{array}{lll}-0.042 & -0.091 & -0.100 \\ (0.040) & (0.065) & (0.070)\end{array}$

Fitted laboe and

transfer income

$\times$ House owner dummy

City-level controls

Household FE

County trend

Province $\times$ year FE

Observations

Number of clusters

$H_{0}$ : Weak instruments

( $p$-value)

\begin{tabular}{|c|c|c|c|c|c|c|c|c|}
\hline & & & & & & $\begin{array}{l}-0.014 \\
(0.081)\end{array}$ & $\begin{array}{l}-0.075 \\
(0.149)\end{array}$ & $\begin{array}{l}-0.121 \\
(0.148)\end{array}$ \\
\hline Yes & Yes & Yes & Yes & Yes & Yes & Yes & Yes & Yes \\
\hline Yes & Yes & Yes & Yes & Yes & Yes & Yes & Yes & Yes \\
\hline Yes & Yes & Yes & Yes & Yes & Yes & Yes & Yes & Yes \\
\hline Yes & Yes & Yes & Yes & Yes & Yes & Yes & Yes & Yes \\
\hline 14,031 & 4,270 & 3,903 & 14,031 & 4,270 & 3,903 & 14,031 & 4,270 & 3,903 \\
\hline 474 & 336 & 328 & 474 & 336 & 328 & 474 & 336 & 328 \\
\hline 0.176 & 0.005 & 0.002 & 0.147 & 0.008 & 0.004 & 0.139 & 0.009 & 0.004 \\
\hline
\end{tabular}


Table 8: Household Consumption and Family Structure

We report 2SLS level regressions in which real annual household consumption is regressed on the household's fitted annual real labor and transfer income and on additional interaction terms identifying family structure. The interaction terms are a dummy for one or more children in the household in Columns (1)-(3), an additional dummy for one or more male children in the household in Columns (4)-(6), or an additional dummy for one or more male children older than 24 years in Columns (7)-(9). The samples consist of all households for which the labor income share $S$ from wages near the minimum wage represent a strictly positive share $(S>0)$, more than $25 \%(S>0.25)$, or more than $50 \%(S>0.5)$, or more than $75 \%(S>0.75)$ of household labor income. All regressions include city level controls, household fixed effects, interacted province-year fixed effects, and county time-trends as specified in Equation (8). We report standard errors clustered at county level in parentheses, twoway clustered at county and city-year level in brackets and two-way clustered at county and province-year level in curly brackets. The $p$-values in the last line refer to a test under the null of weak instruments (Kleibergen and Paap, 2006). Stars ${ }^{* * *},{ }^{* *}$, and ${ }^{*}$ indicate statistical significance at the 1,5 , and 10 percent levels, respectively.

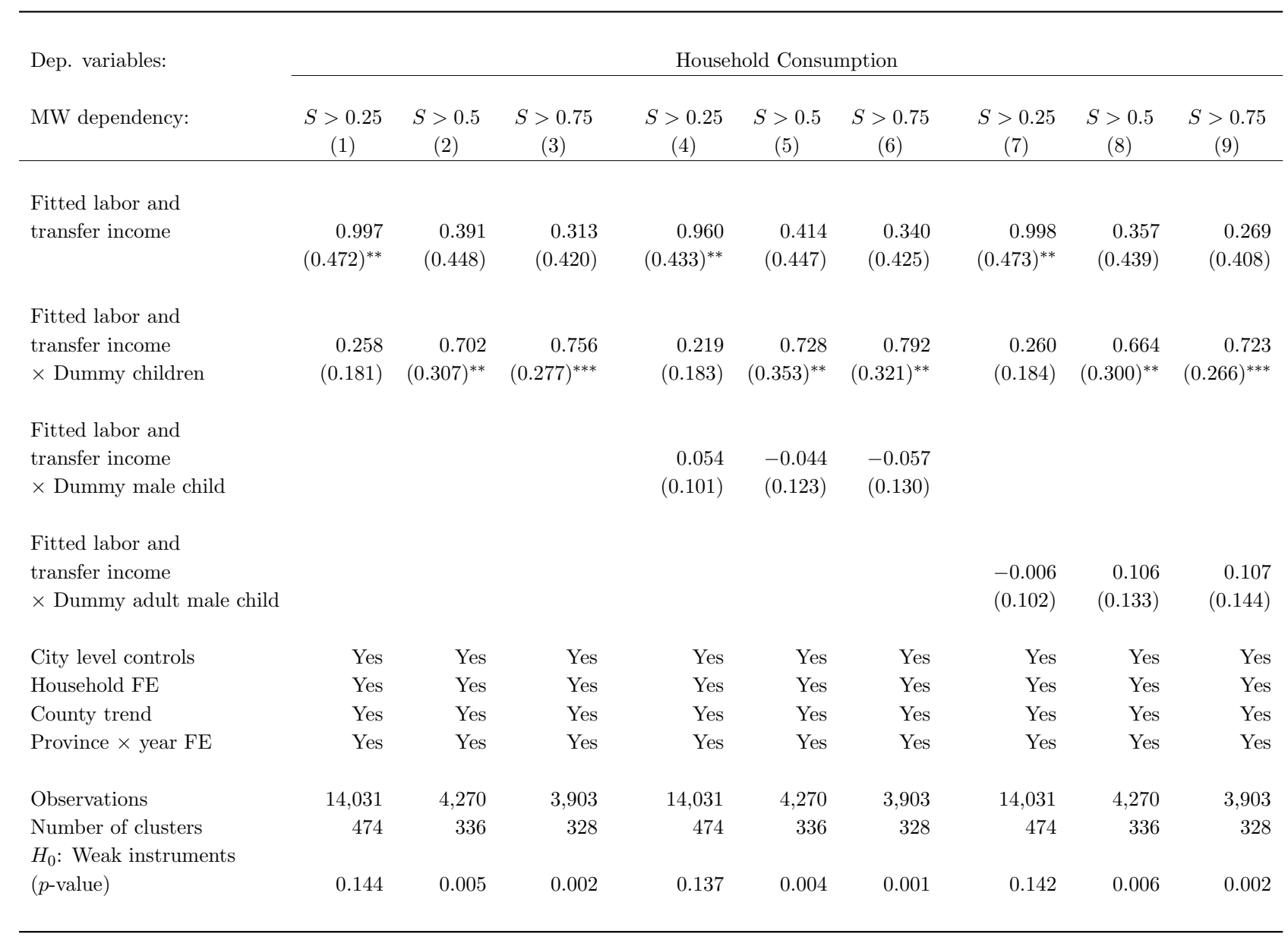


Table 9: Minimum Wages and Employment

We report individual worker level OLS regression with employment dummy as the dependent variable and the $\log$ of the minimum wage level as the independent variable. Regressions in Columns (1)-(4) include all workers and those in Columns (5)-(8) only migrant workers who established their residence in the city in the previous 10 years. Standard errors clustered at county level are shown in parentheses. All regressions include worker fixed effects, province-year fixed effects, and a linear county time trend. We include time varying worker characteristics for age, age squared, a gender dummy, years of work experience, work experience squared, categorical dummies for level of education and marital status. City level controls are city population, city real GDP, city real average wage and city unemployment rate. Stars ${ }^{* *},{ }^{* *}$, and ${ }^{*}$ indicate statistical significance at the 1,5 , and 10 percent levels, respectively. Elasticities can be derived dividing the coefficient (and standard error) on minimum wage by the mean of the dependent variable.

Dep. variable:

Employed (1/0)

\begin{tabular}{|c|c|c|c|c|c|c|c|c|}
\hline \multirow[b]{2}{*}{ MW dependency: } & \multicolumn{4}{|c|}{ All workers } & \multicolumn{4}{|c|}{ Migrant workers } \\
\hline & $\begin{array}{c}\text { All } \\
\text { Households } \\
(5)\end{array}$ & $\begin{array}{c}S>0.25 \\
(6)\end{array}$ & $\begin{array}{c}S>0.5 \\
\quad(7)\end{array}$ & $\begin{array}{c}S>0.75 \\
(8)\end{array}$ & $\begin{array}{c}\text { All } \\
\text { Households } \\
(5)\end{array}$ & $\begin{array}{c}S>0.2 \\
(6)\end{array}$ & $\begin{array}{c}S>0.4 \\
\quad(7)\end{array}$ & $\begin{array}{c}S>0.6 \\
\quad(8)\end{array}$ \\
\hline Log minimum wage & $\begin{array}{r}0.001 \\
(0.019)\end{array}$ & $\begin{array}{l}-0.020 \\
(0.030)\end{array}$ & $\begin{array}{l}-0.044 \\
(0.054)\end{array}$ & $\begin{array}{l}-0.076 \\
(0.057)\end{array}$ & $\begin{array}{l}-0.036 \\
(0.049)\end{array}$ & $\begin{array}{l}-0.081 \\
(0.127)\end{array}$ & $\begin{array}{l}-0.053 \\
(0.250)\end{array}$ & $\begin{array}{l}-0.115 \\
(0.314)\end{array}$ \\
\hline Mean of dep. variable & 0.953 & 0.945 & 0.888 & 0.895 & 0.950 & 0.955 & 0.923 & 0.894 \\
\hline City level controls & Yes & Yes & Yes & Yes & Yes & Yes & Yes & Yes \\
\hline Worker FE & Yes & Yes & Yes & Yes & Yes & Yes & Yes & Yes \\
\hline Province $\times$ year FE & Yes & Yes & Yes & Yes & Yes & Yes & Yes & Yes \\
\hline County trend & Yes & Yes & Yes & Yes & Yes & Yes & Yes & Yes \\
\hline Observations & 163,711 & 33,395 & 10,752 & 9,848 & 13,380 & 2,920 & 1,054 & 751 \\
\hline Number of clusters & 635 & 530 & 391 & 387 & 464 & 285 & 170 & 130 \\
\hline Adjusted $R^{2}$ & 0.907 & 0.905 & 0.930 & 0.928 & 0.949 & 0.941 & 0.982 & 0.982 \\
\hline
\end{tabular}


Table 10: Minimum Wages and Occupation Change

We report individual worker level OLS regression where the dependent variable is a dummy for occupation switching from the previous year (=1 if switch). The exogenous variable is the log of the minimum wage level. Regressions in Columns (1)-(4) include all workers and those in Columns (5)-(8) only migrant workers. To increase the number of observations and the power of the estimates we do not restrict the regressions to recent immigrants. Standard errors clustered at county level are shown in parentheses. All regressions include worker fixed effects, province-year fixed effects and a linear county time trend. We include time varying worker characteristics for age, age squared, a gender dummy, years of work experience, work experience squared, categorical dummies for level of education and marital status. City level controls are city population, city real GDP, city real average wage and city unemployment rate. Stars ${ }^{* * *},{ }^{* *}$, and ${ }^{*}$ indicate statistical significance at the 1, 5, and 10 percent levels, respectively. Elasticities can be derived dividing the coefficient (and standard error) on minimum wage by the mean of the dependent variable.

Dep. variable:

Occupation switch $(1 / 0)$

\begin{tabular}{|c|c|c|c|c|c|c|c|c|}
\hline \multirow[b]{2}{*}{ MW dependency: } & \multicolumn{4}{|c|}{ All workers } & \multicolumn{4}{|c|}{ Migrant workers } \\
\hline & $\begin{array}{c}\text { All } \\
\text { Households } \\
(5)\end{array}$ & $\begin{array}{c}S>0.25 \\
(6)\end{array}$ & $\begin{array}{c}S>0.5 \\
(7)\end{array}$ & $\begin{array}{c}S>0.75 \\
(8)\end{array}$ & $\begin{array}{c}\text { All } \\
\text { Households } \\
(5)\end{array}$ & $\begin{array}{c}S>0.2 \\
(6)\end{array}$ & $\begin{array}{c}S>0.4 \\
(7)\end{array}$ & $\begin{array}{c}S>0.6 \\
(8)\end{array}$ \\
\hline Log minimum wage & $\begin{array}{r}0.067 \\
(0.120)\end{array}$ & $\begin{array}{r}0.069 \\
(0.196)\end{array}$ & $\begin{array}{r}0.066 \\
(0.283)\end{array}$ & $\begin{array}{r}0.208 \\
(0.270)\end{array}$ & $\begin{array}{r}0.059 \\
(0.109)\end{array}$ & $\begin{array}{r}0.125 \\
(0.334)\end{array}$ & $\begin{array}{r}0.357 \\
(0.459)\end{array}$ & $\begin{array}{r}0.656 \\
(0.633)\end{array}$ \\
\hline Mean of dependent variable & 0.079 & 0.089 & 0.092 & 0.088 & 0.080 & 0.092 & 0.095 & 0.094 \\
\hline City level controls & Yes & Yes & Yes & Yes & Yes & Yes & Yes & Yes \\
\hline Worker FE & Yes & Yes & Yes & Yes & Yes & Yes & Yes & Yes \\
\hline Province $\times$ year $\mathrm{FE}$ & Yes & Yes & Yes & Yes & Yes & Yes & Yes & Yes \\
\hline County trend & Yes & Yes & Yes & Yes & Yes & Yes & Yes & Yes \\
\hline Observations & 50,184 & 9,714 & 2,746 & 2,514 & 20,811 & 4,110 & 1,359 & 862 \\
\hline Number of clusters & 280 & 258 & 193 & 184 & 277 & 231 & 161 & 134 \\
\hline Adjusted $R^{2}$ & 0.603 & 0.621 & 0.671 & 0.683 & 0.652 & 0.700 & 0.780 & 0.820 \\
\hline
\end{tabular}




\section{Appendix A: Predicting the Minimum Wage}

For the correct interpretation of econometric estimates, it is important that minimum wage changes in China are non-predictable and can be considered as a random income shocks from the perspective of households. In this section we show that wage changes are indeed non-unpredictable even when using rich information sets with socio-economic and political data typically beyond the reach of individual households.

First, we use county-level socio-economic data to explore the predictability of minimum wage changes. Second, we aggregate the Urban Household Survey (UHS) data and examine whether these alternative county-level aggregates show any predictability for the minimum wage change. Third, we use biographical data on the two most important political decision makers in Chinese counties, namely the mayor and party secretary, to predict minimum wage changes. Throughout this exercise, we code any nominal minimum wage change in a county as a binary $(0 / 1)$ decision. But the results are robust if the (level) change of the minimum wage becomes the dependent variable.

\section{A.1. Predictability Based on County-Level Data}

Table A1 presents OLS regression based on country-level socio-economic data to examine the predictability of minimum wage changes codes as binary outcomes $(0 / 1)$. The socio-economic data are sourced from the Prefecture Statistical Annual Yearbooks, the Fiscal Statistics for Prefectures, Municipalities and Counties and the National Demographic Yearbook. We note that these county level data have an imperfect overlap with the sample of counties in our main data and so we do not use them in the analysis on household consumption. Yet they are still a useful data source for a test of predictability of the minimum wage change.

Columns (1)-(3) include the listed covariates as contemporaneous changes and Columns (4)-(6) as lagged changes. All variables are expressed in real terms using a province-level consumer price deflator. We find that none of the county variables robustly predicts (either as contemporaneous or lagged changes) minimum wage across specifications. In Column (3) only the average salary in the county shows weak negative relation with the decision to change the minimum wage. But this marginal significance disappears when we use two-way clustering at the county and province-year levels (not shown). Overall, we conclude that the results indicate no systematic relationship between county-level socio-economic variables and minimum wage changes.

\section{A.2. Predictability Based on Aggregates of Household Survey Data}

Table A2 explores the predictability of minimum wage changes based on county-level aggregates of the Urban Household Survey (UHS) used throughout the paper. The set of counties covered differs from Table A1 and the time span is restricted to the period 2002-2009. The county-level aggregates of the UHS data are complimented by city-level variables drawn from the China City Statistical Yearbooks in the Chinese Statistical Yearbook Database (CNKI). Again, no statistically significant relationship appears between the various covariates and the minimum wage change. The results also holds if we consider level change in minimum wages as an alternative dependent variable.

\section{A.3. Predictability Based on Biographical Data of Local Political Leaders}

In democratic societies, important political decisions like minimum wage changes are subject to open political debate and depend on the parliamentary strength of competing political parties. Chinese 
politics represents an entirely different political setting, important policy issues can be contingent on the preferences of the key local decision makers, Yao and Zhang (2015). Minimum wage changes in China originate in an administrative and political process that is not subject to a open debate that involves the public at large. This implies that little public information is generated that would allow households to anticipate minimum wage changes. Moreover, the timing of minimum wage changes is highly discretionary across regions and the law only stipulates the requirement of regular review, not a mandatory change. While individual policy preferences are hard to observe, such preferences and policy outcomes could nevertheless be related to personal political career paths and curricula or to demographic characteristics of local leaders.

The two main political actors in Chinese local politics are the mayor, appointed by the local communist party assembly, and the local party secretary, appointed by personal office of the central party administration. Their biographical data are available in the Chinese Bureaucracies and Leaders Database, which is constructed and maintained by the National Chengchi University. ${ }^{26}$ We use biographical information about their respective tenure, their first year in office, the their year of promotion and retirement, as well as their age and experience. Table A3 presents the regression results with seven biographical variables for the local party secretary and an equal number for the local mayor. Yet none of these biographical variables has any predictive value for minimum wage change. Similar results are obtained if we define the dependent variable as first difference in minimum wage levels.

Overall, we conclude from Tables A1, A2 and A3 that minimum wage changes in China are not predictable based on county-level socio-economic data or even biographical data on the two most powerful local politicians.

\footnotetext{
${ }^{26}$ See http://ics.nccu.edu.tw/chinaleaders/. The data are documented in Shih et al. (2010), Yao and Zhang (2015) and Zhou (2016).
} 
Table A1: County-Level Determinants of Minimum Wage Changes, 1997-2010

The minimum wage change as the dependent variable is coded as a binary decision outcome $(1 / 0)$ with 1 representing a change and regressed on various county-level socio-economic variables. Columns (1)-(3) use covariates in first differences contemporaneous with the minimum wage change; Columns (4)-(6) use covariates in first differences lagged by one year relative to the minimum wage change. Standard errors are clustered at county level are shown in parentheses. Stars indicate significance levels at p-values: ${ }^{*} \mathrm{p}<0.1,{ }^{* *} \mathrm{p}<0.05,{ }^{* * *} \mathrm{p}<0.01$.

\begin{tabular}{|c|c|c|c|c|c|c|}
\hline \multirow[t]{3}{*}{ Dep. variable: } & \multicolumn{6}{|c|}{ Minimum wage change dummy $(1 / 0)$} \\
\hline & \multicolumn{3}{|c|}{ Covariates in $\Delta_{t}$} & \multicolumn{3}{|c|}{ Covariates in $\Delta_{t-1}$} \\
\hline & (1) & $(2)$ & $(3)$ & $(4)$ & $(5)$ & (6) \\
\hline \multirow[t]{2}{*}{ Ln(County Real GDP) } & -0.042 & $-0.191^{* * *}$ & -0.005 & $-0.076^{* * *}$ & $-0.097^{* *}$ & -0.012 \\
\hline & $(0.035)$ & $(0.045)$ & $(0.010)$ & $(0.028)$ & $(0.049)$ & $(0.009)$ \\
\hline \multirow[t]{2}{*}{ Ln(County Population) } & -0.077 & $-0.240^{*}$ & 0.005 & 0.165 & 0.176 & 0.012 \\
\hline & $(0.103)$ & $(0.128)$ & $(0.009)$ & $(0.101)$ & $(0.153)$ & $(0.010)$ \\
\hline \multirow[t]{2}{*}{ Ln(County Total Employment) } & -0.014 & -0.011 & -0.001 & 0.004 & 0.007 & -0.000 \\
\hline & $(0.014)$ & $(0.016)$ & $(0.001)$ & $(0.016)$ & $(0.023)$ & $(0.001)$ \\
\hline \multirow[t]{2}{*}{ County Government Balance/GDP } & $-0.001^{* *}$ & -0.001 & -0.000 & -0.000 & -0.000 & 0.000 \\
\hline & $(0.001)$ & $(0.001)$ & $(0.000)$ & $(0.001)$ & $(0.001)$ & $(0.000)$ \\
\hline \multirow{2}{*}{ Ln(County Salary per capita) } & 0.016 & 0.002 & $-0.020^{*}$ & $0.021^{* * *}$ & 0.006 & 0.002 \\
\hline & $(0.013)$ & $(0.013)$ & $(0.011)$ & $(0.007)$ & $(0.007)$ & $(0.001)$ \\
\hline \multirow{2}{*}{ Ln(County Employment in Agriculture) } & $-0.021^{* *}$ & -0.016 & 0.000 & $0.026^{* * *}$ & $0.030^{* *}$ & 0.001 \\
\hline & $(0.009)$ & $(0.010)$ & $(0.001)$ & $(0.009)$ & $(0.012)$ & $(0.001)$ \\
\hline \multirow[t]{2}{*}{ Ln(Real County Savings) } & -0.002 & -0.007 & -0.002 & 0.014 & 0.005 & 0.001 \\
\hline & $(0.015)$ & $(0.016)$ & $(0.002)$ & $(0.013)$ & $(0.019)$ & $(0.001)$ \\
\hline County FE & Yes & Yes & Yes & Yes & Yes & Yes \\
\hline Year FE & Yes & & & Yes & & \\
\hline County Trend & & Yes & Yes & & Yes & Yes \\
\hline Province-year FE & & & Yes & & & Yes \\
\hline Observations & 8716 & 8716 & 8714 & 7139 & 7139 & 7137 \\
\hline Number of clusters & 1651 & 1651 & 1651 & 1647 & 1647 & 1647 \\
\hline Adjusted R-square & 0.591 & 0.697 & 0.990 & 0.625 & 0.686 & 0.992 \\
\hline
\end{tabular}


Table A2: Constructed County-Level Determinants of Minimum Wage Changes, 2002-2009

The minimum wage change as the dependent variable is coded as a binary decision outcome $(1 / 0)$. We construct county-level aggregates from the UHS data and add city level variables. Columns (1)-(2) present estimates with standard errors clustered at the county level; Columns (3)-(4) report standard errors clustered two ways at the county and province-year level. Stars indicate significance levels at p-values: ${ }^{*} \mathrm{p}<0.1,{ }^{* *} \mathrm{p}<0.05,{ }^{* * *} \mathrm{p}<0.01$.

\begin{tabular}{lll}
\hline Dep. variable: & \multicolumn{3}{l}{ Minimum wage change dummy $(0 / 1)$} \\
\cline { 2 - 3 } Standard error clustering: & $\frac{\text { County }}{(1) \quad(2)}$ & $\frac{\text { Two-way }}{(3)}$ \\
\hline
\end{tabular}

County-level variables

$\begin{array}{lllll}\Delta_{t} \operatorname{Ln}(\text { County HH real consumption) } & -0.008 & 0.047 & -0.008 & 0.047\end{array}$

$\begin{array}{rrrr}(0.108) & (0.055) & (0.111) & (0.059) \\ 0.001 & -0.028 & 0.001 & -0.028 \\ (0.092) & (0.039) & (0.105) & (0.451) \\ -0.002 & -0.006 & -0.002 & -0.006 \\ (0.019) & (0.008) & (0.018) & (1.265) \\ -0.183 & 0.089 & -0.183 & 0.089 \\ (0.148) & (0.069) & (0.177) & (2.248)\end{array}$

$\Delta_{t} \operatorname{Ln}($ County HH tot. expend.)

$\Delta_{t} \operatorname{Ln}($ County HH savings)

Share of county SOE workers

$(2.248)$

City-level variables

$\Delta_{t} \operatorname{Ln}($ City real GDP)

$\begin{array}{llll}0.484^{* *} & 0.070 & 0.484 & 0.070\end{array}$

$\Delta_{t} \operatorname{Ln}($ City population $)$

$\begin{array}{llll}(0.211) & (0.111) & (0.450) & (0.753)\end{array}$

$\begin{array}{llll}-0.130 & 0.090 & -0.130 & 0.090\end{array}$

$\begin{array}{llll}(0.084) & (0.068) & (0.144) & (1.214)\end{array}$

$\Delta_{t}$ City unemployment rate

$\begin{array}{llll}0.208 & -0.065 & 0.208 & -0.065\end{array}$

$\begin{array}{llll}(0.273) & (0.148) & (0.335) & (1.511)\end{array}$

$\Delta_{t} \operatorname{Ln}($ Total city employment)

$\begin{array}{llll}0.167 & -0.130 & 0.167 & -0.130\end{array}$

$\begin{array}{llll}(0.199) & (0.133) & (0.330) & (0.507)\end{array}$

$\Delta_{t}$ City employment/population

$\begin{array}{llll}-0.624 & 0.357 & -0.624 & 0.357\end{array}$

$\begin{array}{llll}(1.121) & (1.166) & (1.578) \quad(1.486)\end{array}$

County FE

Year FE

County trends

Province-year FE

Observations

Yes Yes Yes Yes

Number of clusters

Yes

Yes

Yes Yes

Yes Yes

Adjusted R-squared

$\begin{array}{rrrr}591 & 591 & 99 & 99\end{array}$

$\begin{array}{llll}0.353 & 0.973 & 0.676 & 0.973\end{array}$ 
Table A3: Political Characteristics and Minimum Wage Changes, 1997-2010

The minimum wage change as the dependent variable is coded as a binary decision outcome $(1 / 0)$ with 1 representing a change and regressed on the characteristics of thr local party secretary and the mayor. Columns (1)-(2) present estimates with standard errors clustered at the county level; Columns (3)-(4) report standard errors clustered two ways at the county and province-year level. Stars indicate significance levels at $\mathrm{p}$-values: ${ }^{*} \mathrm{p}<0.1,{ }^{* *} \mathrm{p}<0.05,{ }^{* * *} \mathrm{p}<0.01$.

\begin{tabular}{|c|c|c|c|c|}
\hline \multirow{3}{*}{$\begin{array}{l}\text { Dep. variable: } \\
\text { Standard error clustering }\end{array}$} & \multicolumn{4}{|c|}{ Minimum wage change dummy $(1 / 0)$} \\
\hline & \multicolumn{2}{|c|}{ County } & \multicolumn{2}{|c|}{ Two-way } \\
\hline & $(1)$ & $(2)$ & $(3)$ & $(4)$ \\
\hline \multicolumn{5}{|l|}{ Party secretary characteristics: } \\
\hline \multirow[t]{2}{*}{ First year in office dummy } & $0.018^{*}$ & 0.004 & $0.018^{*}$ & 0.004 \\
\hline & $(0.009)$ & $(0.004)$ & $(0.009)$ & $(0.004)$ \\
\hline \multirow[t]{2}{*}{ Promotion year dummy } & $0.049^{*}$ & -0.005 & $0.049^{*}$ & -0.005 \\
\hline & $(0.026)$ & $(0.007)$ & $(0.026)$ & $(0.010)$ \\
\hline \multirow[t]{2}{*}{ Retirement year dummy } & $0.079^{* *}$ & $0.028 * *$ & $0.079^{* *}$ & 0.028 \\
\hline & $(0.034)$ & $(0.013)$ & $(0.034)$ & $(0.017)$ \\
\hline \multirow[t]{2}{*}{ Age } & 0.047 & 0.018 & 0.047 & 0.018 \\
\hline & $(0.057)$ & $(0.016)$ & $(0.055)$ & $(0.028)$ \\
\hline \multirow[t]{2}{*}{$\mathrm{Age}^{2}$} & -0.000 & -0.000 & -0.000 & -0.000 \\
\hline & $(0.001)$ & $(0.000)$ & $(0.001)$ & $(0.000)$ \\
\hline \multirow[t]{2}{*}{ Province experience dummy } & -0.016 & 0.005 & -0.016 & 0.005 \\
\hline & $(0.030)$ & $(0.009)$ & $(0.030)$ & $(0.009)$ \\
\hline \multirow[t]{2}{*}{ City tenure length (years) } & 0.007 & 0.004 & 0.007 & 0.004 \\
\hline & $(0.007)$ & $(0.003)$ & $(0.007)$ & $(0.003)$ \\
\hline \multicolumn{5}{|l|}{ Mayor characteristics: } \\
\hline \multirow[t]{2}{*}{ First year in office dummy } & 0.090 & -0.008 & 0.090 & -0.008 \\
\hline & $(0.091)$ & $(0.026)$ & $(0.085)$ & $(0.026)$ \\
\hline \multirow[t]{2}{*}{ Promotion year dummy } & 0.030 & -0.001 & 0.030 & -0.001 \\
\hline & $(0.023)$ & $(0.005)$ & $(0.025)$ & $(0.007)$ \\
\hline \multirow[t]{2}{*}{ Retirement year dummy } & -0.016 & -0.001 & -0.016 & -0.001 \\
\hline & $(0.043)$ & $(0.013)$ & $(0.043)$ & $(0.018)$ \\
\hline \multirow[t]{2}{*}{ Age } & -0.003 & 0.006 & -0.003 & 0.006 \\
\hline & $(0.052)$ & $(0.017)$ & $(0.063)$ & $(0.018)$ \\
\hline \multirow[t]{2}{*}{$\mathrm{Age}^{2}$} & 0.000 & -0.000 & 0.000 & -0.000 \\
\hline & $(0.001)$ & $(0.000)$ & $(0.001)$ & $(0.000)$ \\
\hline \multirow[t]{2}{*}{ Province experience dummy } & 0.024 & 0.003 & 0.024 & 0.003 \\
\hline & $(0.023)$ & $(0.006)$ & $(0.026)$ & $(0.008)$ \\
\hline \multirow[t]{2}{*}{ City tenure length (years) } & 0.090 & -0.007 & 0.090 & -0.007 \\
\hline & $(0.091)$ & $(0.025)$ & $(0.084)$ & $(0.025)$ \\
\hline County FE & Yes & Yes & Yes & Yes \\
\hline Year FE & Yes & & Yes & \\
\hline County Trend & & Yes & & Yes \\
\hline Province-year FE & & Yes & & Yes \\
\hline Observations & 14548 & 14544 & 14548 & 14544 \\
\hline Number of clusters & 258 & 257 & 232 & 228 \\
\hline Adjusted R-square & 0.383 & 0.964 & 0.383 & 0.964 \\
\hline
\end{tabular}




\section{Appendix B: Sample Construction}

\section{B.1. Household Data Selection}

China's Urban Household Survey (UHS) has two components. At the household level, we dispose of data on various consumption items and household income. At the level of household members, additional data captures household member income, income type, employment status, years of education, years of work experience, etc. We merge the household survey data with the minimum wage data at county and city level from the Chinese Ministry of Human Resources and add additional macroeconomic variables at the county and city level. All monetary variables are converted in real terms using the province-level urban CPI index with the base year 2002. The raw data constitutes a panel of 201,795 household-year observations and 773,330 household-member-year cells for the period 2002-2009. The following data filters are applied to the household data:

1. We only retain households that are observed at least twice in the panel (i.e. we drop 68,779 household-year observations).

2. We retain only households reporting in their first year of sampling at least two wage earning household members (i.e. we drop 59,624 household-year observations). Wage-earning household members are those who are potentially affected by minimum wage changes.

3. We eliminate households that provide contradictory information about the household head and for which we cannot compute the share $S$ (228 household-year observations).

The final data set comprises 73,164 household-year observations. Descriptive statistics of the main variables and family demographics are shown in Tables A4 and A5 respectively.

\section{B.2. Identifying the Two Highest Wage Earners within the Household}

For minimum wages changes to matter for household income, a family needs to earn a positive share of its total household income from labor income near or at the minimum wage. Within each household, we identify the two highest wage earners conditioning on the first year the individual is observed in the panel. The selection of wage earners within each household follows these principles:

1. We ignore self-employed individuals (30,971 member-year observations); retired household members (124,901); retired and then re-employed household members (11,396), incapacitated persons $(8,396)$, homeworkers $(61,343)$, soldiers, social volunteers or part-time employed workers $(17,879)$, students $(56,737)$ and other household members undergoing training $(251)$.

2. We ignore household members outside the labor force: below 16 years of age $(75,317)$ and above 59 for males $(2,566)$ and above 54 for females $(2,363)$.

3. We ignore household members with inconsistent records where they are reported as unemployed and nevertheless receive a positive labor income (6363).

4. We ignore members with incomplete reporting on labor income $(6,694)$ and workers with an annual real wage lower than $50 \%$ of the annual real minimum wage $(12,293)$.

5. We ignore workers with abnormally high increases in their real wage (above 1000\%) between the first and last year of observation in the panel (187). 
6. We ignore household members with inconsistent age records that increase by more than one from one year to another or decrease $(6,553)$ and household members who are not relatives $(210)$.

The two highest wage earners within the household are in most cases $(80.5 \%)$ the head of the household and the spouse. We retain for the household-level regressions their wage income, age, gender, level of education and years of work experience, years since migration to the city, marital status, industry and occupation.

\section{B.3. Minimum Wage Dependency of a Household}

Finally, we define the share $\mathrm{S}$ of household income coming from the wage income (of the two highest wage earners) at or near the minimum wage. We consider a wage earner to earn a minimum wage if her salary ranges between $50 \%$ and $150 \%$ of the real minimum wage of their county of residence in the first year the individual is observed in the panel. Conditioning on the first year of household observation assures that the treated household group remains unchanged over time.

Among the two highest wage earners of all retained households, we identify 32,580 (18.72\%) treated (minimum wage) and 141,442 (81.28 percent) non-treated worker-year observations. We also undertake extensive robustness checks with respect to a narrower salary range from $50 \%$ to $120 \%$ of the local minimum wage, which results in 18,721 (10.76\%) and 155,301 (89.24\%) non-treated worker-year observations, respectively.

Table A4 reports summary statistics on the households income and expenditure components for household groups sorted by their minimum wage income share S. Column (1) includes all households, Column (2) with $S=0$ all households without wage income at or near the minimum wage, whereas Columns (3)-(5) feature household groups of increasing minimum wage dependency. 
Table A4: Incomes and Expenditures Share of Disposable Income

We summarize the household income and expenditure components as a share of disposable income by different household types sorted by their share $S$ of minimum wage income in total household income. Data are from the Urban Household Survey (UHS) and cover the period from 2002 to 2009. Reported are average values for the entire period and standard errors are in parentheses below.

\begin{tabular}{lrrrrr}
\hline MW dependency: & All & $\mathrm{S}=0$ & $\mathrm{~S}>0$ & $\mathrm{~S}>0.5$ & $\mathrm{~S}>0.75$ \\
& Households & & & & \\
\hline & & & & & \\
Income components: & & & & & \\
Labor income & 0.902 & 0.917 & 0.862 & 0.779 & 0.792 \\
& $(0.158)$ & $(0.140)$ & $(0.192)$ & $(0.243)$ & $(0.242)$ \\
Transfer income & 0.083 & 0.069 & 0.120 & 0.195 & 0.185 \\
& $(0.146)$ & $(0.128)$ & $(0.181)$ & $(0.234)$ & $(0.233)$ \\
Transfer income net of pension & 0.041 & 0.035 & 0.055 & 0.082 & 0.068 \\
& $(0.081)$ & $(0.071)$ & $(0.100)$ & $(0.124)$ & $(0.106)$ \\
& & & & & \\
Expenditure components: & & & & & \\
Consumption & 0.724 & 0.705 & 0.773 & 0.820 & 0.817 \\
& $(0.311)$ & $(0.310)$ & $(0.308)$ & $(0.359)$ & $(0.364)$ \\
Housing expenditure & 0.055 & 0.060 & 0.040 & 0.035 & 0.031 \\
& $(0.491)$ & $(0.502)$ & $(0.458)$ & $(0.441)$ & $(0.420)$ \\
Education expenditure & 0.112 & 0.112 & 0.111 & 0.103 & 0.102 \\
& $(0.125)$ & $(0.119)$ & $(0.139)$ & $(0.154)$ & $(0.155)$ \\
Health expenditure & 0.043 & 0.041 & 0.048 & 0.054 & 0.053 \\
& $(0.084)$ & $(0.075)$ & $(0.105)$ & $(0.116)$ & $(0.117)$ \\
Durables expenditure & 0.039 & 0.041 & 0.036 & 0.032 & 0.032 \\
Savings & $(0.060)$ & $(0.063)$ & $(0.051)$ & $(0.042)$ & $(0.042)$ \\
& 0.240 & 0.264 & 0.179 & 0.143 & 0.146 \\
Observations & $(0.309)$ & $(0.324)$ & $(0.254)$ & $(0.228)$ & $(0.232)$ \\
Share of observations in sample & & & & & \\
Share of total labor income & & 0.72 & 0.27 & 0.06 & 0.05 \\
\hline & & 0.819 & 0.181 & 0.026 & 0.024 \\
\hline
\end{tabular}


Table A5: Household Demographics

We summarize the household demographics by household type sorted on the share $S$ of minimum wage earnings in total household income. Data are from the Urban Household Survey (UHS) and cover the period 2002-2009. Reported are average values for the entire period and standard errors are in parentheses below. Family head refers to the household member with the highest labor income; SOE stands for State Owned Enterprise; education is a categorical variable with a total of nine categories: no schooling, basic literacy classes, primary school, junior high school, senior middle school, secondary, college enrollment, bachelor completed, graduated.

\begin{tabular}{lrrrrr}
\hline MW dependency: & All & $\mathrm{S}=0$ & $\mathrm{~S}>0$ & $\mathrm{~S}>0.5$ & $\mathrm{~S}>0.75$ \\
& Households & & & & \\
\hline \multirow{3}{*}{ Family size } & 3.145 & 3.118 & 3.215 & 3.345 & 3.355 \\
& $(0.724)$ & $(0.703)$ & $(0.773)$ & $(0.862)$ & $(0.869)$ \\
House ownership & 0.870 & 0.890 & 0.818 & 0.778 & 0.776 \\
& $(0.336)$ & $(0.313)$ & $(0.386)$ & $(0.415)$ & $(0.417)$ \\
Years since migrating & 8.047 & 8.429 & 7.040 & 6.047 & 6.149 \\
& $(11.10)$ & $(11.15)$ & $(10.91)$ & $(10.63)$ & $(10.69)$ \\
SOE employee share & 0.735 & 0.778 & 0.620 & 0.436 & 0.441 \\
& $(0.441)$ & $(0.415)$ & $(0.485)$ & $(0.496)$ & $(0.497)$ \\
Female Head & 0.270 & 0.292 & 0.211 & 0.318 & 0.316 \\
& $(0.444)$ & $(0.455)$ & $(0.408)$ & $(0.466)$ & $(0.465)$ \\
Age of the family head & 41.38 & 41.29 & 41.62 & 40.58 & 40.47 \\
Family head education & $(7.842)$ & $(7.742)$ & $(8.095)$ & $(8.686)$ & $(8.754)$ \\
Head work experience (years) & 5.914 & 6.127 & 5.351 & 4.929 & 4.941 \\
& $(1.441)$ & $(1.419)$ & $(1.345)$ & $(1.172)$ & $(1.174)$ \\
& 20.87 & 20.84 & 20.95 & 19.35 & 19.23 \\
Observations & $(8.703)$ & $(8.590)$ & $(8.995)$ & $(9.804)$ & $(9.859)$ \\
& & & & & \\
& 73164 & 53054 & 20110 & 4365 & 3990 \\
\hline
\end{tabular}




\section{Appendix C: Specification Issues}

\section{Table A6: Alternative First-Stage Regressions}

Household annual real labor income is regressed on the annual real minimum wage for households sorted by the share $\mathrm{S}$ of household minimum wage income in total income under two alternative specifications. Columns (1)-(4) do not include linear county time trends and province-year fixed effects in the specification, while Columns (5)-(8) control for linear county time trends and province-year fixed effects. We report standard errors clustered at county level in parentheses, two way clustered errors at county and city-year level in brackets and two-way clustered errors at county and province-year level in curly brackets. Stars indicate significance levels at the following p-values: ${ }^{*} \mathrm{p}<0.1,{ }^{* *} \mathrm{p}<0.05,{ }^{* * *} \mathrm{p}<0.01$. All regressions include controls for the two highest labor income earners in the household, namely age and age squared, a gender dummy, years of work experience and work experience squared, years since migration to the city and squared, family size as measured by the number of family members and a house ownership dummy. Additional categorical control variables characterize the level of education, marital status, industry and occupation. City-level variation is accounted for by city population, city real GDP, city real average wage and city unemployment rate.

\begin{tabular}{|c|c|c|c|c|c|c|c|c|}
\hline \multirow{3}{*}{$\begin{array}{l}\text { Dep. variable: } \\
\text { MW dependency: }\end{array}$} & \multicolumn{8}{|c|}{ Household Real Labor Income } \\
\hline & \multicolumn{4}{|c|}{ Household FE and year FE } & \multicolumn{4}{|c|}{ County trends and province-year FE } \\
\hline & $\begin{array}{c}S=0 \\
(1)\end{array}$ & $\begin{array}{c}S>0 \\
(2) \\
\end{array}$ & $\begin{array}{c}S>0.5 \\
(3)\end{array}$ & $\begin{array}{c}S>0.75 \\
(4) \\
\end{array}$ & $\begin{array}{c}S=0 \\
(5)\end{array}$ & $\begin{array}{c}S>0 \\
(6)\end{array}$ & $\begin{array}{c}S>0.5 \\
(7)\end{array}$ & $\begin{array}{c}S>0.75 \\
(8)\end{array}$ \\
\hline \multirow{2}{*}{$\begin{array}{l}\text { Real Minimum } \\
\text { Wage (in RMB) }\end{array}$} & & & & & & & & \\
\hline & $\begin{array}{r}1.222 \\
(0.296)^{* * *} \\
{[0.316]^{* * *}} \\
\{0.386\}^{* * *}\end{array}$ & $\begin{array}{r}1.832 \\
(0.388)^{* * *} \\
{[0.547]^{* * *}} \\
\{0.526\}^{* * *}\end{array}$ & $\begin{array}{r}2.161 \\
(0.562)^{* * *} \\
{[0.618]^{* * *}} \\
\{0.829\}^{* *}\end{array}$ & $\begin{array}{r}1.976 \\
(0.568)^{* * *} \\
{[0.639]^{* * *}} \\
\{0.833\}^{* *}\end{array}$ & $\begin{array}{r}0.012 \\
(0.524) \\
{[0.521]} \\
\{0.570\}\end{array}$ & $\begin{array}{r}0.507 \\
(0.473) \\
{[0.497]} \\
\{0.496\}\end{array}$ & $\begin{array}{r}1.378 \\
(0.636)^{* *} \\
{[0.660]^{* *}} \\
\{0.750\}^{*}\end{array}$ & $\begin{array}{r}1.563 \\
(0.743)^{* *} \\
{[0.771]^{* *}} \\
\{0.878\}^{*}\end{array}$ \\
\hline Observations & 51,330 & 19,728 & 4,270 & 3,903 & 51,330 & 19,728 & 4,267 & 3899 \\
\hline Number of clusters & 600 & 508 & 336 & 328 & 600 & 508 & 336 & 328 \\
\hline Adjusted R-square & 0.925 & 0.861 & 0.820 & 0.821 & 0.930 & 0.883 & 0.889 & 0.889 \\
\hline Household FE & Yes & Yes & Yes & Yes & Yes & Yes & Yes & Yes \\
\hline Year FE & Yes & Yes & Yes & Yes & & & & \\
\hline County trends & & & & & Yes & Yes & Yes & Yes \\
\hline Province-year FE & & & & & Yes & Yes & Yes & Yes \\
\hline
\end{tabular}




\section{Appendix D: OLS Estimates of the Income Elasticity of Consumption}

Table A7: OLS Estimates of the Income Elasticity of Consumption

We report OLS regressions, where Columns (1)-(4) estimate the income elasticity of consumption using household real labor income as the main regressor of interest, whereas Columns (5)-(6) use the sum of labor and transfer incomes as the main regressor of interest. We report standard errors clustered at county level in parentheses, two-way clustered errors at the county and city-year level in brackets, and two way clustered errors at the county and province-year level in curly brackets. Stars indicate significance levels at the following p-values: ${ }^{*} \mathrm{p}<0.1,{ }^{* *} \mathrm{p}<0.05,{ }^{* * *} \mathrm{p}<0.01$. All regressions include controls for the two highest labor income earners in the household, namely age and age squared, a gender dummy, years of work experience and work experience squared, years since migration to the city and squared, family size as measured by the number of family members and a house ownership dummy. Additional categorical control variables characterize the level of education, marital status, industry and occupation. City-level variation is accounted for by city population, city real GDP, city real average wage and city unemployment rate.

\begin{tabular}{|c|c|c|c|c|c|c|c|c|}
\hline \multirow{2}{*}{$\begin{array}{l}\text { Dep. variable: } \\
\text { MW dependency: }\end{array}$} & \multicolumn{8}{|c|}{ Annual Real Household Consumption } \\
\hline & $\begin{array}{c}S=0 \\
(1)\end{array}$ & $\begin{array}{c}S>0 \\
(2)\end{array}$ & $\begin{array}{c}S>0.5 \\
(3)\end{array}$ & $\begin{array}{c}S>0.75 \\
(4)\end{array}$ & $\begin{array}{c}S=0 \\
(5)\end{array}$ & $\begin{array}{c}S>0 \\
(6)\end{array}$ & $\begin{array}{c}S>0.5 \\
(7)\end{array}$ & $\begin{array}{c}S>0.75 \\
(8)\end{array}$ \\
\hline $\begin{array}{l}\text { Household real } \\
\text { labor income }\end{array}$ & $\begin{array}{r}0.398 \\
(0.039)^{* * *} \\
{[0.040]^{* * *}} \\
\{0.041\}^{* * *}\end{array}$ & $\begin{array}{r}0.439 \\
(0.020)^{* * *} \\
{[0.020]^{* * *}} \\
\{0.025\}^{* * *}\end{array}$ & $\begin{array}{r}0.405 \\
(0.082)^{* * *} \\
{[0.083]^{* * *}} \\
\{0.089\}^{* * *}\end{array}$ & $\begin{array}{r}0.387 \\
(0.081)^{* * *} \\
{[0.081]^{* * *}} \\
\{0.088\}^{* * *}\end{array}$ & & & & \\
\hline $\begin{array}{l}\text { Household real } \\
\text { labor and transfer } \\
\text { income }\end{array}$ & & & & & $\begin{array}{r}0.388 \\
(0.031)^{* * *} \\
{[0.031]^{* * *}} \\
\{0.032\}^{* * *}\end{array}$ & $\begin{array}{r}0.437 \\
(0.023)^{* * *} \\
{[0.024]^{* * *}} \\
\{0.025\}^{* * *}\end{array}$ & $\begin{array}{r}0.359 \\
(0.076)^{* * *} \\
{[0.077]^{* * *}} \\
\{0.077\}^{* * *}\end{array}$ & $\begin{array}{r}0.334 \\
(0.079)^{* * *} \\
{[0.080]^{* * *}} \\
\{0.081\}^{* * *}\end{array}$ \\
\hline $\begin{array}{l}\text { Observations } \\
\text { Number of clusters } \\
\text { Adjusted R-square }\end{array}$ & $\begin{array}{r}19,728 \\
508 \\
0.809\end{array}$ & $\begin{array}{r}14,031 \\
474 \\
0.836\end{array}$ & $\begin{array}{r}4,267 \\
336 \\
0.862\end{array}$ & $\begin{array}{r}3,899 \\
328 \\
0.868\end{array}$ & $\begin{array}{r}19,728 \\
508 \\
0.812\end{array}$ & $\begin{array}{r}14,031 \\
474 \\
0.838\end{array}$ & $\begin{array}{r}4,267 \\
336 \\
0.868\end{array}$ & $\begin{array}{r}3,899 \\
328 \\
0.876\end{array}$ \\
\hline $\begin{array}{l}\text { Household FE } \\
\text { County trends } \\
\text { Province-year FE }\end{array}$ & $\begin{array}{l}\text { Yes } \\
\text { Yes } \\
\text { Yes }\end{array}$ & $\begin{array}{l}\text { Yes } \\
\text { Yes } \\
\text { Yes }\end{array}$ & $\begin{array}{l}\text { Yes } \\
\text { Yes } \\
\text { Yes }\end{array}$ & $\begin{array}{l}\text { Yes } \\
\text { Yes } \\
\text { Yes }\end{array}$ & $\begin{array}{l}\text { Yes } \\
\text { Yes } \\
\text { Yes }\end{array}$ & $\begin{array}{l}\text { Yes } \\
\text { Yes } \\
\text { Yes }\end{array}$ & $\begin{array}{l}\text { Yes } \\
\text { Yes } \\
\text { Yes }\end{array}$ & $\begin{array}{l}\text { Yes } \\
\text { Yes } \\
\text { Yes }\end{array}$ \\
\hline
\end{tabular}




\section{Appendix E: Parallel Trends and Anticipation Effects}

Table A8: Reduced Form Estimates for Augmented Specification

Reduced form specifications regress the annual real household consumption in RMB on the contemporaneous real local minimum wage level and alternatively lags of one and two years in Columns (1)-(4) and leads of one and two years in Columns (5)-(8). The samples consist of all households for which the labor income share $S$ from wages near the minimum wage represent a strictly positive share $(S>0)$, more than $25 \%(S>0.25)$, or more than $50 \%(S>0.5)$, or more than $75 \%(S>0.75)$ of household labor income. All regressions include household, county and interacted province-year fixed effects. We control for all other type of income including transfers, we add city level controls, and county time trends as specified in Equation (9). We report standard errors clustered at county level in parentheses, two-way clustered at county and city-year level in brackets and two-way clustered at county and province-year level in curly brackets. Stars ${ }^{* * *},{ }^{* *}$, and ${ }^{*}$ indicate statistical significance at the 1,5 , and 10 percent levels respectively.

\begin{tabular}{|c|c|c|c|c|c|c|c|c|}
\hline \multirow{3}{*}{$\begin{array}{l}\text { Dep. variable: } \\
\text { MW dependency: }\end{array}$} & \multicolumn{8}{|c|}{ Annual Real Household Consumption } \\
\hline & \multicolumn{4}{|c|}{ Delayed Income Effects } & \multicolumn{4}{|c|}{ Anticipated Income Effects } \\
\hline & $\begin{array}{c}S=0 \\
(1)\end{array}$ & $\begin{array}{c}S>0 \\
(2)\end{array}$ & $\begin{array}{c}S>0.5 \\
(3)\end{array}$ & $\begin{array}{c}S>0.75 \\
(4)\end{array}$ & $\begin{array}{c}S=0 \\
(5)\end{array}$ & $\begin{array}{c}S>0 \\
(6)\end{array}$ & $\begin{array}{c}S>0.5 \\
(7)\end{array}$ & $\begin{array}{c}S>0.75 \\
(8)\end{array}$ \\
\hline Minimum wage & $\begin{array}{r}0.989 \\
(0.628)\end{array}$ & $\begin{array}{r}1.459 \\
(0.619)^{* *}\end{array}$ & $\begin{array}{r}2.349 \\
(0.935)^{* *}\end{array}$ & $\begin{array}{r}2.523 \\
(1.071)^{* *}\end{array}$ & $\begin{array}{r}1.002 \\
(0.675)\end{array}$ & $\begin{array}{r}0.991 \\
(0.684)\end{array}$ & $\begin{array}{r}1.398 \\
(0.722)^{*}\end{array}$ & $\begin{array}{r}1.663 \\
(0.812)^{* *}\end{array}$ \\
\hline Minimum wage $_{t-1}$ & $\begin{array}{c}-0.619 \\
(0.524)\end{array}$ & $\begin{array}{r}-0.458 \\
(0.597)\end{array}$ & $\begin{array}{l}-1.245 \\
(1.018)\end{array}$ & $\begin{array}{l}-1.212 \\
(1.076)\end{array}$ & & & & \\
\hline Minimum wage $_{t-2}$ & $\begin{array}{r}-0.136 \\
(0.686)\end{array}$ & $\begin{array}{r}0.704 \\
(0.689)\end{array}$ & $\begin{array}{r}0.802 \\
(1.391)\end{array}$ & $\begin{array}{r}0.616 \\
(1.443)\end{array}$ & & & & \\
\hline Minimum wage ${ }_{t+1}$ & & & & & $\begin{array}{r}0.218 \\
(0.527)\end{array}$ & $\begin{array}{r}-0.098 \\
(0.461)\end{array}$ & $\begin{array}{l}-0.743 \\
(0.801)\end{array}$ & $\begin{array}{l}-0.785 \\
(0.849)\end{array}$ \\
\hline Minimum wage ${ }_{t+2}$ & & & & & $\begin{array}{r}0.034 \\
(0.549)\end{array}$ & $\begin{array}{r}-0.100 \\
(0.322)\end{array}$ & $\begin{array}{r}0.065 \\
(0.460)\end{array}$ & $\begin{array}{r}0.056 \\
(0.585)\end{array}$ \\
\hline $\mathrm{HH} \mathrm{FE}$ & Yes & Yes & Yes & Yes & Yes & Yes & Yes & Yes \\
\hline County Trend & Yes & Yes & Yes & Yes & Yes & Yes & Yes & Yes \\
\hline Province-year FE & Yes & Yes & Yes & Yes & Yes & Yes & Yes & Yes \\
\hline Observations & 19,728 & 14,031 & 4,265 & 3,897 & 19,728 & 14,031 & 4,265 & 3,897 \\
\hline Number of clusters & 508 & 474 & 335 & 327 & 508 & 474 & 335 & 327 \\
\hline Adjusted R-square & 0.790 & 0.809 & 0.843 & 0.851 & 0.790 & 0.809 & 0.843 & 0.851 \\
\hline
\end{tabular}

